\title{
Jumping spiders: An exceptional group for comparative cognition studies
}

\author{
Samuel Aguilar-Arguello ${ }^{1} \cdot$ Ximena J. Nelson ${ }^{1}$ (D) \\ Accepted: 10 September 2020 / Published online: 14 January 2021 \\ (C) The Psychonomic Society, Inc. 2021
}

\begin{abstract}
Several non-mutually exclusive hypotheses have been proposed to explain the evolution of cognition in animals. Broadly, these hypotheses fall under two categories: those that pertain to the selective pressures exerted either by sociality or by the ecological niche in which animals live. We review these ideas and then discuss why the highly visual jumping spiders (Salticidae) are excellent models for investigating how cognitive ability evolves. With few exceptions, these behaviorally complex spiders are non-social, making them ideal candidates to explore ideas pertaining to selection based on habitat complexity and selection based on predatory behavior (foraging niche hypotheses). With the exception of Antarctica, salticids are found in all habitats on Earth, ranging from very complex to barren and simple. While many species are generalist predators, a minority also have specialized predatory behavior and prey specialization on dangerous prey, which has been proposed as an explanation for advanced cognitive ability. As this large group has a diversity of habitats in which it lives, diverse predatory behavior, as well as some "social" species, we argue that salticids are ideal candidates for comparative studies to explore the myriad selection factors acting upon a group well known for their cognitive prowess, despite having miniature brains.
\end{abstract}

Keywords Comparative cognition · Perception · Object recognition · Categorization · Attention · Spatial learning

\section{The cognitive landscape}

Cognition refers to any state of information processing (Dukas, 2002), including how it is acquired and how it translates into behavior (Shettleworth, 2010). Cognitive processes include memory, perception, decision-making, and learning. Although cognition influences behavioral traits that affect an animal's ecology and evolution (Dukas, 2008), cognitive abilities are simultaneously affected by genetic and environmental factors (Plomin, DeFries, Knopik, \& Neiderhiser, 2013; Richards 1987), as "no behavior is strictly learned or entirely innate" (Shettleworth, 2010). Instead, innate behavior is dominated by inherited traits, requires little internal processing, and changes relatively little with experience, while experience-based behaviors can be innately triggered, but are modified or adjusted depending on experience

Ximena J. Nelson

ximena.nelson@canterbury.ac.nz

1 School of Biological Sciences, University of Canterbury, Private Bag 4800, Christchurch 8140, New Zealand and interaction with the environment (Menzel, 2013; Shettleworth, 2010).

Neural integration processes and cognitive ability can differ as a consequence of the specific demands provided by the life-history of each species (Dunbar, 1998; Menzel, 2013). Consequently, cognition exists as a continuum, from the most basic type of learning (e.g., habituation), as found in marine mollusks with simple nervous systems, such as Aplysia (Castellucci, Pinsker, Kupfermann, \& Kandel, 1970), to social learning and episodic-like memory, such as that found in primates, among others (Crystal, 2018; Menzel, 1999; Menzel et al., 2005; Reader \& Laland, 2002; Reader, Hager, \& Laland, 2011; Schwartz, Meissner, Hoffman, Evans, \& Frazier, 2004).

Factors that affect cognitive capacity include individual genetic variation (Mery \& Kawecki, 2002; Mery, 2013), the level of sociality of species (Barton, 1999; Joffe \& Dunbar, 1997; Reader et al., 2011), brain size (e.g., absolute brain size: Reader \& Laland, 2002; Sol, 2009; relative hippocampus size: Krebs, Sherry, Healy, Perry, \& Vaccarino, 1989; Sherry, Vaccarino, Buckenham, \& Herz, 1989; Krebs, 1990), foraging strategy, and the structural complexity of the environment (Falk, Biebach, \& Krebs, 1992). Furthermore, in primates, ecological, social and technical abilities are significantly 
correlated, suggesting that, at least in social species that include elements of culture, a modular approach to investigating cognition may not be best practice (Reader et al., 2011).

Environmental complexity affects both individual cognitive capacity through developmental plasticity - for example, exploratory behavior is increased in spiders reared in enriched cages instead of empty cages (Carducci \& Jakob, 2000; Liedtke, Redekop, Schneider, \& Schuett, 2015) - and can also affect cognition at a species level. For example, using three species of Myotis bats, Clarin et al. (2013) found that species that forage in complex and less predictable habitats tend to perform better in complex rule-learning tasks than bats that forage in simpler and more predictable environments. Thus, there is a clear feedback loop between genetic and environmental factors that influence cognitive ability (Mery, 2013; Rampon, Tang, Goodhouse, Shimizu, Kyin, \& Tsien, 2000; van Praag, Kempermann, \& Gage, 2000) to facilitate rapid learning in response to changes in the environment, leading to fitness benefits (Chittka, Rossiter, Skorupski, \& Fernando, 2012).

In this review, we argue that the meta-analytical approach used by Reader et al. (2011) on primates can only be performed if there are significant data on a large number of contributing factors (e.g., sociality, foraging strategy, etc.) for a large number of species. In the absence of this, we must begin by amassing those data. For three main reasons, we argue that jumping spiders (Salticidae) are an excellent group in which to do so. Firstly, salticids are known to have complex cognitive behavior, despite having a small nervous system (i.e., relatively few neurons), which is often thought to be crucial to complex cognition, particularly in the vertebrate literature. Secondly, they are a diverse group encompassing a variety of habitats and foraging strategies, making them ideal for comparative studies on the ecological and foraging factors that may contribute to the evolution of cognition. Finally, salticids are a largely non-social group of animals, which largely rules out hypotheses based on sociality; however, some species do live together, permitting an examination of social effects on cognition. We begin by providing an overview of the leading hypotheses that drive variation in cognition and then discuss how these relate to salticid cognition, focusing in particular on ecological factors, before suggesting avenues for future work.

\section{What drives variation in cognition?}

Several hypotheses have been proposed to explain the evolution of cognition and interspecific differences in cognition. These include the Social Brain Hypothesis, the Ecological Intelligence Hypothesis, the Adaptive Specialization Hypothesis, the Extractive Foraging Hypothesis, the Spatial Cognition Hypothesis, the Foraging Niche Hypothesis, and the Clever Foraging Hypothesis. These can be divided into three main groups: (1) Those that link brain size and cognitive capacity with the complexity of social interactions (e.g., social brain hypothesis); (2) those that link cognitive capacity with habitat complexity and stochasticity (e.g., ecological intelligence hypothesis, extractive foraging hypothesis, adaptive specialization hypothesis, spatial cognition hypothesis, foraging niche hypothesis, clever foraging hypothesis); and, in a very similar vein, (3) those that link foraging methods with cognitive capacity (e.g., extractive foraging hypothesis, adaptive specialization hypothesis, foraging niche hypothesis, clever foraging hypothesis). Of these, there are two clear, and non-mutually exclusive, patterns: social ramifications on cognition ("group" 1) and ecological drivers promoting increased cognitive ability ("groups" 2 and 3).

The social brain hypothesis suggests that animals that form big groups are subject to selective effects on information-processing, which favor brain development to manage complex relationships within group members (Dunbar, 1992, 1998). These relationships may involve the recognition and interpretation of visual signals, memory for facial recognition, ability to process emotional information, use of tactical deception, etc. (Dunbar, 1998; Reader et al., 2011). The hypothesis has been corroborated in several mammals (e.g., Barton \& Dunbar, 1997; Dunbar \& Bever, 1998; Gittleman, 1986; Marino, 1996), and, in birds, there is a correlation between relative brain size and the level of pairbonding, suggesting that relationship complexity (e.g., behavioral synchronization, long-term relationships) favors the development of a larger brain (Dunbar, 2009; Shultz \& Dunbar, 2007). However, this hypothesis fails to predict the brain/group size relationship in several other vertebrates (Beauchamp \& Fernández-Juricic, 2004; Byrne, 1997; Finarelli \& Flynn, 2009; Maclean, Barrickman, Johnson, \& Wall, 2009; Shultz \& Dunbar, 2006, 2007) and is not widely applicable in insects (but see Kamhi, Gronenberg, Robson, \& Traniello, 2016), where level of sociality may be correlated with more specialized, rather than larger, brains (Lihoreau, Latty, \& Chittka, 2012). This is referred to as either the task-specialization hypothesis or the distributed-cognition hypothesis. Social insect species may even have restricted cognitive ability compared to solitary species because individuals of eusocial species have a limited range of behaviors due to division of labor, whereas solitary species perform a wider range of behaviors (Chittka \& Niven, 2009; Farris, 2016).

The ecological-intelligence hypothesis proposes that ecological factors create constraints that affect animal cognition (Milton, 1981; Sol, Duncan, Blackburn, Cassey, \& Lefebvre, 2005; Sol, 2009; Rosati, 2017). Constraints can be dietary, including the complex spatiotemporal distribution of foods and the use of extractive foraging techniques (extractive-foraging hypothesis), or responses to a fluctuating environment (Clutton-Brock \& Harvey, 1980; Rosati, 2017). For example, in birds, foraging behavior may be the dominant driver for the 
evolution of cognitive ability (Krebs, 1990). The adaptivespecialization hypothesis (Pravosudov \& Roth, 2013) proposes that the need for caching food for survival during winter was the principal ecological factor that contributed to an enhancement of spatial memory and its underlying neural mechanisms, such as hippocampal volume, in food-caching birds (Biegler, McGregor, Healy \& Krebs, 2001; Hampton \& Shettleworth, 1996; Krebs et al., 1989; Krebs, 1990; Pravosudov \& Roth, 2013; Sherry \& Vaccarino, 1989; Sherry et al., 1989).

A variant of the adaptive specialization hypothesis is the spatial-cognition hypothesis (Barton \& Dunbar, 1997), which is also related to the foraging-niche hypothesis. These explain, correspondingly, the effect of home range size and the distribution of available food on cognitive ability (Clutton-Brock \& Harvey, 1980), and have been corroborated in bats (Eisenberg \& Wilson, 1978; Pirlot \& Stephan, 1970; Stephan, Nelson \& Frahm, 1981), primates (Clutton-Brock \& Harvey, 1980; Harvey, Clutton-Brock, \& Mace, 1980; Mace, Harvey, \& Clutton-Brock, 1981) and rodents (Harvey et al., 1980). The premise is that frugivorous species require good spatial memory for the location of food patches and perhaps an ability to estimate travel routes between them (Clutton-Brock \& Harvey, 1980), while the food of leaf-eating or insectivorous species is more densely distributed and predictable in time and space (Clutton-Brock \& Harvey, 1977). It then may follow that species with bigger home range sizes and patchily distributed food should present better cognitive abilities (or relatively larger brains) than those with a more homogeneous food distribution and smaller home ranges (Clutton-Brock \& Harvey, 1980; Harvey \& Krebs, 1990).

Finally, another hypothesis related to the ecologicalintelligence hypothesis is the clever-foraging hypothesis, which postulates that individuals living in more complex environments have better cognitive abilities, especially in the spatial domain (Byrne, 2016; Costanzo, Bennett, \& Lutermann, 2009; Park \& Bell, 2010; Parker \& Gibson, 1977; Striedter, 2005). Comparative studies in bats and fish evaluating the brain morphology underpinning spatial ability in relation to environmental complexity support this idea (Bauchot, Bauchot, Platel, \& Ridet, 1977; Striedter, 2005; Safi \& Deckman, 2005; Park \& Bell, 2010; but see Ahmed, Thompson, Bolnick, \& Stuart, 2017). Additionally, individual differences have been observed due to the features of the environment in which animals develop, with improvements in spatial memory tasks and exploratory behavior when reared in enriched environments (Carducci \& Jakob, 2000; du Toit, Bennett, Nickless, \& Whiting, 2012; Frick \& Fernandez, 2003; Frick, Stearns, Pan, \& Berger-Sweeney, 2003; Liedtke et al., 2015; Nilsson, Perfilieva, Johansson, Orwar, \& Eriksson, 1999; Williams et al., 2001). These results are mirrored by comparisons between lab-reared and field-collected Phidippus audax salticids, which show differences in color preferences, aggression, courtship and exploratory behavior (Wiggins, Bounds, \& Wilder, 2018).

Comparative studies on spatial ability depending on environmental complexity in invertebrates are scarce. A striking example can be observed in desert ants, in which navigational abilities are more strongly influenced by environmental complexity than phylogenetic relatedness. Melophorus bagoti, which inhabits a landmark-rich semi-desertic environment with visual "beacons," such as tussocks, shrubs, and rocks, relies more on beacons to orient than Melophorus sp. and Cataglyphis fortis, which live in visually barren environments (salt-pans; Schultheiss et al., 2016; Schwarz \& Cheng, 2010). Besides being closely related, M. bagoti and Melophorus sp. also have different navigation behavior (Schultheiss et al., 2016). By relying more on path integration (navigation mechanism based on idiothetic cues, see below) than on visual cues, the behavior of Melophorus sp. is more similar to that of C. fortis than M. bagoti (Cheng, Narendra, \& Wehner, 2006; Narendra, Cheng, \& Wehner, 2007; Schultheiss, Schwarz, Cheng, \& Wehner, 2013). Furthermore, intraspecific differences have been observed in M. bagoti: in rare cases in which colonies are located in areas without beacons, these individuals rely more on path integration than on visual cues (Cheng, Middleton, \& Wehner, 2012; Narendra, 2007). Schwarz and Cheng (2010) suggest that natural selection could have determined the capacity of each ant species to rely on each navigation mechanism depending on the characteristics of the environment in which it lives.

Invertebrates show considerable promise as candidates for work in this area. Even though attempts to compare cognitive abilities between spider species are rare (Eberhard, 2007; Eberhard \& Wcislo, 2011), comparative studies on salticids suggest that cognitive ability is graded (Aguilar-Arguello, Gerhard, \& Nelson, 2019, 2020; Cross \& Jackson, 2016; Tarsitano \& Jackson, 1992, 1994). Here, we argue that salticids, which are generally not social, are especially well suited to investigate ecological drivers for cognitive ability, while largely controlling for the effects of social drivers.

\section{Salticid visual ability}

With over 6,000 described species (World Spider Catalog, 2019), the family Salticidae is the largest in the order Araneae. Salticids usually have a stout body and short legs, and are cursorial predators that typically do not build webs to catch prey. Instead, like solitary felines, they visually locate and approach their prey, attacking by pouncing on the prey from a distance (Foelix, 2011). In addition to their namesake behavioral characteristic of jumping, either to catch prey or when roaming their environment, their most outstanding attribute is vision. Salticids are diurnal (Tork, 2018) and return to their silk cocoon-like nest at night, although some species 
have the ability to see in deep crepuscular conditions (Cerveira, Jackson, \& Nelson, 2019). Salticid behavior is complex, and a range of studies support the existence of multiple cognitive abilities (e.g., see Table 1), largely enabled by their visual prowess (e.g., Cross \& Jackson, 2016; Jackson \& Cross, 2011; Jakob, Skow, Popson, Haberman, \& Plourde, 2007; Jakob, Skow, \& Long, 2011; Skow \& Jakob, 2005).

Salticids are among the most visually guided animals known (Land, 1969a). Unlike other spider families, salticids rely heavily on vision to perform activities such as predation, navigation, and courtship. They have four pairs of cameratype eyes consisting of a single lens that projects onto a retina, together encompassing a visual field of almost $360^{\circ}$ (Land, $1985 \mathrm{a}, \mathrm{b})$. Of the four eye pairs, three (although one pair is often vestigial) are called secondary eyes, despite the fact that these have high resolving power (from $0.4^{\circ}$ to $2^{\mathrm{o}}$; Land \& Fernald, 1992; Land, 2005; Zurek, Taylor, Evans, \& Nelson, 2010). However, their visual system is unusual mainly due to their forward-facing principal eyes (anterior medial eyes), which have spatial acuity vastly exceeding any other animal with a similar eye size (up to $0.04^{\circ}$; Blest, O'Carroll, \& Carter 1990; Williams \& McIntyre, 1980; Land, 1981, 1985a). Briefly, the principal eyes consist of the cornea, the lens, a long eye tube, and a boomerang-shaped retina lying at the end of the eye-tube (Land, 1969a). The retina comprises four layers of photoreceptors that have color discrimination ability that varies from dichromatic to tetrachromatic, depending on species (Harland, Li, \& Jackson, 2012; Zurek, Cronin, Taylor, Byrne, Sullivan \& Morehouse, 2015), and enable depth perception (Nagata et al., 2012). The principal eyes have a narrow field of view of $3-5^{\circ}$, but they are able to compensate for this because the retinae can be moved laterally up to $35^{\circ}$ on either side of the body axis; the retinae can also move vertically, and can rotate on-axis in order to track a specific object (Land, 1969b).

There is considerable variation in vision between different salticid species, not only in terms of the number of colors that they are able to perceive, but also in terms of the degree of the spatial acuity of their principal eyes (varying roughly between $0.13^{\circ}$ and $0.04^{\mathrm{o}}$; Harland et al., 2012), the visual fields covered by the different pairs of eyes (Land, 1985a), and their ability to see in low light conditions (i.e., sensitivity; Cerveira et al., 2019). Furthermore, there are sex differences in responses to stimuli of different contrasts (i.e., contrast sensitivity is higher in females than in males; Zurek \& Nelson, 2012a), and this mirrors known sex (and age) differences in behavior, including motivation to attack prey, type of food sourced, or preferred prey (Jackson, Nelson, \& Sune, 2005; Li \& Jackson, 1996; Nelson \& Jackson, 2012a, 2013). This suggests that any comparative work on salticids should take into consideration what is known about the visual system of the species - and even the sexes - being compared. For example, some species may perform better than others on color-related learning and memory tasks, which are commonly used in salticid studies (e.g., Jakob et al., 2007; Leidke \& Schneider, 2014; Raška, Štys, \& Exnerová, 2017; Taylor, Amin, Maier, Byrne, \& Morehouse, 2016; VanderSal \& Hebets, 2007; Table 1), not because of inherently better cognitive ability, but simply because they may have better color discrimination ability.

Salticid vision is highly complex not only because of the principal eyes, but also because of the interaction between these and the secondary eyes. The latter have a motiondetection function, informing the spider about moving objects in their visual field and initiating optomotor responses to face the moving object in order to further identify it in detail with the principal eyes (Zurek et al., 2010; Zurek \& Nelson, 2012a,b). Fundamentally, it is likely that vision has emancipated salticids from their webs and enabled them to become active diurnal hunters (Harland, Li, \& Jackson 2012; Jackson \& Blest, 1982), and this, in turn, may have significantly affected the cognitive abilities for which they are famous.

\section{Salticid spatial ability}

Central-place foragers are animals that move from a central point (e.g., burrow, nest) to forage or find a mate (OrtegaEscobar, 2006). Arthropods, of which the best-studied cases are hymenopterans, often rely on a set of different cues and mechanisms to find their way back to this central point. One of the most frequently used mechanisms is path integration: an internal representation of the position of the individual with respect to a fixed origin (Honkanen, Adden, da Silva Freitas, \& Heinze, 2019). This idiothetic mechanism frequently updates the distance and direction travelled by the animal and can therefore integrate this information to determine a vector to a known point (Collett \& Graham, 2004). Thus, after a circuitous outbound route, desert ants can return to their nest in a straight line by using path integration. However, this mechanism is not perfect, as the longer the distance travelled, the less reliable is the position estimation. Due to the accumulation of errors in the path integrator, the use of other mechanisms, such as landmarks (beacons), allow these insects to calibrate their path integrator and ensure their orientation with respect to known points, such as the nest (Heinze, Narendra, \& Cheung, 2018; Wehner \& Wehner, 1990).

Path integration has been observed in some burrowing spiders, such as lycosids, the funnel web spider (Agelena labyrinthica), the nocturnal ctenid spider (Cupiennius salei), and the Namib desert spider (Leucorchestris arenicola) (Görner \& Claas, 1985; Moller \& Görner, 1994; OrtegaEscobar; 2002; Nørgaard, Henschel, \& Wehner, 2003; Seyfarth, Hergenröder, Ebbes, \& Barth, 1982). While salticids typically do not burrow, they often live in complex threedimensional environments and, at dusk, normally return to 
Table 1 Representative lab (upper section) and field (lower section) studies on spatial ability in salticids, and details of habitat in which they are found

\begin{tabular}{|c|c|c|c|c|}
\hline Reference & Task function (1-5) and test type & Species & Habitat & Success* \\
\hline \multirow[t]{2}{*}{ Heil, 1936} & \multirow[t]{2}{*}{ 1.1. Detour } & Evarcha arcuata & \multirow[t]{2}{*}{ Sunny clearings, near railroads (Germany) } & Yes \\
\hline & & Evarcha falcata & & Yes \\
\hline \multirow[t]{2}{*}{ Hill, 1979} & \multirow[t]{2}{*}{ 1. Detour } & $\begin{array}{l}\text { Phidippus } \\
\text { pulcherrimus }\end{array}$ & Prairies (USA) & Yes \\
\hline & & Phidippus regius & Prairies (USA) & Yes \\
\hline \multirow[t]{7}{*}{ Tarsitano \& Jackson, 1992} & \multirow[t]{7}{*}{ 1. Detour } & Portia fimbriata & Tropical rainforest (Australia) & Yes \\
\hline & & Portia labiata & Tropical rainforest (Sri Lanka) & Yes \\
\hline & & Euophrys parvula & Ground dweller, temperate rainforest (NZ) & Yes \\
\hline & & Euryattus sp. & Tropical rainforest (Australia) & Yes \\
\hline & & Marpissa marina & Rocky shores (NZ) & Yes \\
\hline & & Trite auricoma & $\begin{array}{l}\text { Ground and vegetation; wide habitat range } \\
\text { (NZ) }\end{array}$ & Yes \\
\hline & & Trite planiceps & Coastal area shrubs (NZ) & Yes \\
\hline \multirow{2}{*}{ Tarsitano \& Jackson 1994} & \multirow{2}{*}{ 1. Reverse-route detour test } & Portia fimbriata & Tropical forest (Australia) & Yes \\
\hline & & Trite planiceps & Coastal area shrubs (NZ) & Yes \\
\hline Tarsitano \& Jackson, 1997 & $\begin{array}{l}\text { 1. Reverse-route detour test; lure } \\
\text { hidden from sight }\end{array}$ & Portia fimbriata & Tropical rainforest (Australia) & Yes \\
\hline Tarsitano \& Andrew, 1999 & $\begin{array}{l}\text { 1. Choice: incorrect and correct } \\
\text { detour route }\end{array}$ & Portia labiata & Tropical rainforest (Sri Lanka) & Yes \\
\hline Carducci \& Jakob, 2000 & 1. Reverse-route detour test & Phidippus audax & Woods and long grass (USA) & Yes \\
\hline Tarsitano, 2006 & $\begin{array}{l}\text { 1. Choice: incorrect and correct } \\
\text { detour route }\end{array}$ & Portia labiata & Tropical rainforest (Sri Lanka) & Yes \\
\hline \multirow[t]{15}{*}{ Cross \& Jackson, 2016} & \multirow{15}{*}{$\begin{array}{l}\text { 1. Choice: incorrect and correct } \\
\text { detour } \\
\text { route; reverse detour and hidden } \\
\text { lure }\end{array}$} & Brettus adonis & Rainforest (Sri Lanka) & Yes \\
\hline & & Brettus albolimbatus & Rainforest (Sri Lanka) & Yes \\
\hline & & Cocalus gibbosus & Tropical rainforest (Australia) & Partial \\
\hline & & Cyrba algerina & Open woodland in xeric areas (Portugal) & Partial \\
\hline & & Cyrba ocellata & Open woodland in xeric areas (Kenya) & Yes \\
\hline & & Cyrba simoni & Savanna (Kenya) & Yes \\
\hline & & Gelotia lanka & Rainforest (Sri Lanka) & Yes \\
\hline & & Meleon solitaria & Forested area (Uganda) & Yes \\
\hline & & $\begin{array}{l}\text { Neobrettus } \\
\quad \text { nangalisargus }\end{array}$ & Agricultural lowlands (Philippines) & Yes \\
\hline & & Portia africana & Savanna (Kenya) & Yes \\
\hline & & Portia albimana & Lowland Rainforest (Sri Lanka) & Yes \\
\hline & & Portia fimbriata & Tropical rainforest (Australia) & Yes \\
\hline & & Portia labiata & Rainforest (Sri Lanka) & Yes \\
\hline & & Portia cf. occidentalis & Agricultural lowlands (Philippines) & Partial \\
\hline & & Portia schultzi & $\begin{array}{l}\text { Coastal palm belt and lowland rainforest } \\
\text { (Kenya) }\end{array}$ & Yes \\
\hline \multirow[t]{2}{*}{ Cross \& Jackson, 2019} & \multirow{2}{*}{$\begin{array}{l}\text { 1. Reverse-route detour test } \\
\text { 1. Shortcut versus detour test }\end{array}$} & \multirow[t]{2}{*}{ Portia africana } & \multirow[t]{2}{*}{ Savanna (Kenya) } & Yes \\
\hline & & & & Yes \\
\hline Jackson, Carter, \& Tarsitano, 2001 & $\begin{array}{l}\text { 2. Two-step confinement problem } \\
\text { and } \\
\text { trial-and-error learning }\end{array}$ & Portia fimbriata & Tropical forest (Australia) & Yes \\
\hline \multirow[t]{2}{*}{ Jackson, Cross, \& Carter, 2006} & \multirow{2}{*}{$\begin{array}{l}\text { 2. Two-step confinement problem } \\
\text { and } \\
\text { trial-and-error learning }\end{array}$} & Portia labiata & Pine forest (Philippines) & No \\
\hline & & Portia labiata & Tropical rainforest (Philippines) & Yes \\
\hline \multirow[t]{9}{*}{ Cross \& Jackson, 2015} & \multirow[t]{9}{*}{ 2. Two-step confinement problem } & Brettus adonis & Rainforest (Sri Lanka) & Yes \\
\hline & & Brettus albolimbatus & Rainforest (Sri Lanka) & Yes \\
\hline & & Cyrba algerina & Open woodland in xeric areas (Portugal) & Yes \\
\hline & & Cyrba ocellata & Open woodland in xeric areas (Kenya) & Yes \\
\hline & & Cyrba simoni & Rainforest (Sri Lanka) & Yes \\
\hline & & Portia africana & Savanna (Kenya) & Yes \\
\hline & & Portia schultzi & $\begin{array}{l}\text { Coastal palm belt/ lowland rain-forest } \\
\text { (Kenya) }\end{array}$ & Yes \\
\hline & & Cocalus gibbosus & Tropical forest (Australia) & No \\
\hline & & Paracyrba wanlessi & Fallen bamboo culms (Malaysia) & No \\
\hline \multirow[t]{4}{*}{$\begin{array}{l}\text { Aguilar-Arguello, Gerhard \& } \\
\quad \text { Nelson, } 2019\end{array}$} & $\begin{array}{l}\text { 1/2. Choice: correct and three } \\
\text { incorrect routes }\end{array}$ & Marpissa marina & Rocky shores (NZ) & No \\
\hline & $\begin{array}{l}\text { 1/2. Choice: lured and control } \\
\text { routes }\end{array}$ & & & No \\
\hline & 1/2. Choice: short and long routes & & & No \\
\hline & $\begin{array}{l}\text { 1/2. Choice: correct and three } \\
\text { incorrect routes }\end{array}$ & Trite planiceps & Coastal area shrubs (NZ) & No \\
\hline
\end{tabular}


Table 1 (continued)

\begin{tabular}{|c|c|c|c|c|}
\hline Reference & Task function (1-5) and test type & Species & Habitat & Success* \\
\hline \multirow{6}{*}{$\begin{array}{l}\text { Aguilar-Arguello, Gerhard \& Nelson, } \\
2020\end{array}$} & $\begin{array}{l}\text { 1/2. Choice: lured and control } \\
\text { routes }\end{array}$ & & & \\
\hline & 1/2. Choice: short and long routes & \multirow{3}{*}{ Trite planiceps } & \multirow{3}{*}{ Coastal area shrubs (NZ) } & Yes \\
\hline & 2. Route assessment & & & No \\
\hline & 2. Shortcut test & & & $\begin{array}{l}\text { Only in } \\
\text { males }\end{array}$ \\
\hline & 2. Route assessment & \multirow[t]{2}{*}{ Portia fimbriata } & \multirow[t]{2}{*}{ Tropical forest (Australia) } & Yes \\
\hline & 2. Shortcut test & & & Yes \\
\hline Peckmezian \& Taylor, 2015a & $\begin{array}{l}\text { 3. Nest location by use of beacons } \\
\text { in virtual reality }\end{array}$ & Servaea incana & Eucalyptus trees (Australia) & Yes \\
\hline Nakamura \& Yamashita, 2000 & $\begin{array}{l}\text { 5.Heat-avoidance learning in } \\
\text { association with color }\end{array}$ & Hasarius adansoni & Open fields and near buildings (Japan) & Yes \\
\hline $\begin{array}{l}\text { Jakob, Skow, Haberman, \& Plourde, } \\
2007\end{array}$ & $\begin{array}{l}\text { 5. Color-food association in } \\
\text { T-maze }\end{array}$ & Phidippus princeps & Grass and wildflowers (USA) & Yes \\
\hline Liedtke \& Schneider, 2014 & $\begin{array}{l}\text { 5. Learning and reversal learning. } \\
\text { Color-food association }\end{array}$ & Marpissa muscosa & Bark-dweller in black pine (Germany) & Yes \\
\hline Jakob \& Long, 2016 & $\begin{array}{l}\text { 5. Heat-avoidance learning in } \\
\text { association with color }\end{array}$ & Phidippus audax & Woods and long grass (USA) & No \\
\hline Jakob \& Long, 2016 & $\begin{array}{l}\text { 5. Association of heat and visual } \\
\text { texture in a T-maze }\end{array}$ & Marpissa muscosa & Bark-dweller in black pine (Germany) & No \\
\hline Liedtke \& Schneider, 2017 & $\begin{array}{l}\text { 5. Learning and reversal learning. } \\
\text { Color-food association }\end{array}$ & Marpissa muscosa & Bark-dweller in black pine (Germany) & Yes \\
\hline VanderSal \& Hebets, 2007 & $\begin{array}{l}\text { 5. Color discrimination learning } \\
\text { associated with vibrations and } \\
\text { heat }\end{array}$ & Habronattus dossenus & Leaf litter, rocks or sand (USA) & Yes \\
\hline Peckmezian \& Taylor, 2015b & $\begin{array}{l}\text { 5. Association between electric } \\
\text { shock and shaded or lit area }\end{array}$ & Servaea incana & Eucalyptus trees (Australia) & Yes \\
\hline Peckmezian \& Taylor, 2017 & $\begin{array}{l}\text { 5. Association between electric } \\
\text { shock and black/white back- } \\
\text { ground }\end{array}$ & Servaea incana & Eucalyptus trees (Australia) & Yes \\
\hline Jakob \& Long, 2016 & 5. Learning in water maze & Phidippus audax & Woods and long grass (USA) & No \\
\hline \multicolumn{5}{|l|}{ Field studies } \\
\hline \multirow[t]{2}{*}{ Jackson \& Hallas, 1986b } & \multirow{2}{*}{$\begin{array}{l}\text { 4. Males make detours to approach } \\
\text { females }\end{array}$} & Portia labiata & Lowland rainforest (Malaysia) & Yes \\
\hline & & Portia schultzi & $\begin{array}{l}\text { Coastal palm belt/ lowland rainforest } \\
\text { (Kenya) }\end{array}$ & Yes \\
\hline Hill, 1979 & 4. Approach female & Phidippus audax & Lake margins (USA) & Yes \\
\hline Jackson \& Wilcox, 1993 & 1. Detour & Portia fimbriata & Tropical forest (Australia) & Yes \\
\hline Hoefler \& Jakob, 2006 & 3. Nest location by use of beacons & Phidippus clarus & Grass and shrubs (USA) & Yes \\
\hline
\end{tabular}

*Whether the task is successful or not determined by authors

Task function: 1. Predation, 2. Confinement problem, 3. Homing, 4. Courtship, 5. T-maze, associative, and color-based learning

NZ New Zealand

their cocoon-like silk nests (Jackson, 1979; Mooney \& Haloin, 2009) by using visual cues or beacons (Hoefler \& Jakob, 2006). Their navigational ability is highlighted by the fact that, due to habitat characteristics, rather than walking a straight line, salticids are sometimes forced to take detours, defined as an indirect route taken by an animal when the direct route is blocked (Jakob et al., 2011), in order to reach a goal. Several salticid species have been demonstrated to take detours to access prey (Cross \& Jackson, 2016; Tarsitano \& Jackson, 1992, 1994; Table 1), which suggests that this is a common behavior in this family. It is unlikely that, when moving through their environment, salticids use stereotyped paths, so they need to constantly make decisions about routes leading towards a specific goal (e.g., prey, nest, mate). These decisions directly affect the individual's fitness, as an incorrect route translates into more time exposed to predators, more energy loss (Gibson, Wasserman, \& Kamil, 2007), or, when the aim is a prey item, a missed opportunity for a meal.

Detouring is an elaborate cognitive process, as it implies route planning after assessing several possible alternatives (Cheng, 2016). Detours can consist of several components; for example, climbing down a branch that is connected to a twig, which connects to a leaf on which the prey sits. Here, spiders not only have to remember the relative position of the primary objective (prey), but also the selection of an access route involving secondary objectives (the branch or twig). In moving towards a secondary objective, the spider commonly turns away from the position of the target prey, and therefore must retain a memory or internal representation of the relative position (location) of that prey at all times (Hill, 1979; 
Tarsitano \& Jackson, 1992; Tarsitano \& Andrew, 1999; Tarsitano, 2006). Sometimes, after moving towards the detour, the salticid performs a series of "re-orientations" in order to keep track of the primary objective (Hill, 1979). Upon reaching the secondary objective, the spider focuses its attention on the next objective that will bring it closer to its goal (Hill, 1979). Depending on the complexity of the detour, Hill (2007) suggested the use of tertiary, and perhaps even quaternary, objectives in salticids. Re-orientations are fast and precise: the cephalothorax turns the angle required so that the principal eyes point towards the objective, without apparent error. This internal representation of the prey's location and its idiothetic calibration, coupled with the spider's displacement, has been interpreted as evidence of path integration (Hill, 2007). While this mechanism is not with respect to a central place, and thus does not satisfy the criteria commonly applied for path integration, it is evidently in some part idiothetic. Nevertheless, while path integration has been traditionally thought to be used for homing, it has been demonstrated that this is a mechanism used by Drosophila to memorize the location of a food source (Kim \& Dickinson 2017). This opens up the possibility that other arthropods, including salticids, may use path integration for purposes other than homing.

From studies in nature and in the laboratory (Table 1), we now know that salticids can solve tasks that suggest the ability to: (a) remember the position of the objective from the beginning of the detour, (b) use detours that initially take the spider away from the goal, and (c) assess which detours lead, and which do not lead, to the desired objective (Cross \& Jackson, 2016, 2019; Tarsitano \& Jackson, 1997). However, with few exceptions (e.g., Aguilar-Arguello et al., 2020; Cross \& Jackson, 2019), there is little information about what features of a detour are actually accounted for in making decisions. In other words, when multiple routes lead to an objective, are more efficient, or less risky routes identified and preferred? Are some species better able to identify these routes? How does this correlate with the complexity of the habitat in which they evolved?

\section{The exceptional case of Portia}

Species in the genus Portia are famously clever by salticid standards. Portia is classified within the subfamily Spartaeinae (Maddison et al., 2014), which often specializes on preying on other spiders - dangerous prey to tackle (Cross \& Jackson, 2016). This genus currently comprises 17 species, which live in very complex three-dimensional tropical rainforest habitats in which they prey upon different spider species (Harland \& Jackson, 2000a, 2001; Jackson \& Blest, 1982; Jackson \& Wilcox, 1990). This genus is known for outstanding cognitive ability and behavioral flexibility (Jackson \& Pollard, 1996; Jackson \& Cross, 2011) - a "jack-of-all-trades, master of all," as referred to by Jackson and Hallas (1986a). Portia uses specific strategies to hunt each one of its wide variety of spider prey. From entering a web in order to eat the resident spider (Cerveira, Jackson, \& Guseinov, 2003; Jackson \& Nelson, 2011), to avoiding attacking spitting spiders, Scytodes, from the front - where they can be in range of their sticky defensive spit - or indeed choosing to hunt Scytodes holding eggsacs in their mouths (Jackson, Pollard, Li, \& Fijn, 2002; Li \& Jackson, 2003), Portia's predatory flexibility and specialization is unmatched by other well-studied salticids (e.g., Phidippus: Edwards \& Jackson, 1993, 1994; Freed, 1984; Gardner, 1965; Givens, 1978; Jackson, 1977; Evarcha culicivora: Cross \& Jackson 2009a,b; Nelson, Jackson, \& Sune, 2005; Myrmarachne: Jackson, 1986a; Jackson \& Willey, 1994; Nelson \& Jackson, 2009a), including other spartaeines (e.g., Cerveira, Jackson, \& Guseinov, 2003; Guseinov, Cerveira, \& Jackson, 2004; Harland, Jackson, \& Li, 2012; Jackson, 1990a,b,c,d). This is mirrored in Portia's spatial ability, which is characterized by scanning phases that allow Portia to plan a detour ahead of time and choose the best route to reach a goal (Cross \& Jackson, 2016; Jackson \& Wilcox, 1993; Tarsitano \& Jackson, 1992; Tarsitano \& Andrew, 1999; Tarsitano, 2006). In nature, detours can be over $127 \mathrm{~cm}$ long, and the spider can be out of sight from its prey for over $80 \mathrm{~min}$ (Jackson \& Wilcox, 1993), implying not only an outstanding sense of orientation in three-dimensional space, but, due to the spider's need to move away from the prey's position to follow the detour, also acute spatial memory. This ability is seen, at least to some extent, in other salticid species (e.g., AguilarArguello et al., 2019, 2020; Forster, 1982; Heil, 1936; Hill, 1979, 2007).

In contrast to primate evolution, which has favored cognitive complexity over time (Byrne, 2000), in salticids the subfamily Spartaeinae (to which Portia belongs) is relatively ancestral (Maddison et al., 2014, 2017). The explanation for Portia's outstanding cognitive ability has not yet been answered, but like most salticids, it is typically not social, so hypotheses related to the social brain hypothesis are unlikely. In contrast, because Portia's habitat and preference for dangerous prey (spiders can kill Portia and thus pose a significant risk) requires them to make complex detours to reach the prey and often to walk through the prey spider's web (Jackson \& Hallas, 1986a,b; Jackson \& Wilcox, 1993), ecologically derived and foraging niche-based hypotheses seem more likely, although as yet large comparative investigations have not been performed. Comparative studies with a limited number of species, do, however, support these ideas (e.g., Aguilar-Arguello et al., 2020; Cross \& Jackson, 2016). Indeed, the very fact that salticids are typically non-social makes them ideal candidates to investigate the relative importance 
of foraging niche and habitat complexity-based hypotheses.

Risk assessment can provide insight into cognitive ability To solve problems, animals can either have cognitive processes that allow them to evaluate the costs and benefits of a certain behavior or decision (use of declarative knowledge), or they can simply follow a "rule of thumb" (use of procedural knowledge) that does not necessitate decision-making. Decisionmaking is a fundamental cognitive process that allows animals to evaluate their environment so they can avoid less favorable situations. In contrast to procedural knowledge mechanisms, decision-making allows animals to adapt and adjust to unpredictable environmental changes. Examples of decisionmaking include choosing mates (Bateson, 1983), selecting a place to live (Partridge, 1978), and where to forage (Stephens \& Krebs, 1986). A related process - assessment - is how animals evaluate perceived stimuli, convert these to an informational state, and then infer a specific level of risk or benefit (Blumstein \& Bouskila, 1996) of a given decision. Therefore, decision-making is the cognitive process that occurs between assessment and an observable behavior (Blumstein \& Bouskila, 1996).

Assessment in vertebrates has been well documented and includes assessment of mate quality (Dick \& Elwood, 1989; Halliday, 1983), patch quality (Stephens \& Krebs, 1986), resource-holding potential (Dowds \& Elwood, 1983; Riechert, 1982), and predation risk (Bouskila \& Blumstein, 1992; Lima \& Dill, 1990), among others. Assessment of predation entails another important component: risk. Survival depends greatly on the capacity of an organism to avoid biologically dangerous situations. Therefore, the avoidance of danger requires the ability to discriminate between - and make decisions about - stimuli that could be harmful from stimuli that signify harmless or beneficial situations (Schiff, Caviness, \& Gibson, 1962). For example, in the context of predation, some vertebrates are able to assess the risk of being attacked depending on predator distance, the proximity to their own refuge, the approaching speed of the predator, and the number of nearby conspecifics (Stankowich \& Blumstein, 2005). In salticids, a clear example of risk assessment is found in Phintella piatensis. This unusual salticid associates with ants, particularly Oecophylla smargadina weaver ants, which it does not hunt. Weaver ants pose a considerable (and lethal) risk to the salticid, but can provide benefits in terms of reduced predation by ant-averse predators, including by spitting spiders, Scytodes sp. Phintella piatensis evaluates the risk posed by weaver ants during courtship and mating, choosing to mate inside their unusually dense "ant-proof" nests only when ants are visible. Moreover, $P$. piatensis uses both odor and visual cues to determine the presence of weaver ants, which in turn elicits nest-building behavior (Nelson \& Jackson, 2009b, 2014).

The last example shows that decision-making and assessment can be informed not only by the use of one sensory modality, but by multisensory information (Dall \& Johnstone, 2002; Dall, Giraldeau, Olsson, McNamara, \& Stephens, 2005; Sih, 1992), sometimes improving the individuals' response (Partan \& Marler 1999; Partan, Larco, \& Owens, 2009; Smith \& Belk, 2001). The use of multisensory cues on decision-making has been shown in assessment of predation risk (e.g., fish: Martin, Fodrie, Heck, \& Mattila, 2010; Smith \& Belk, 2001; Ward \& Mehner, 2010; crabs: Hazlett \& McLay, 2005; grey squirrels: Partan et al., 2009), communication (e.g., ants: Hölldobler, 1999), and interactions with abiotic aspects of the environment (e.g., butterflies: Johnson \& Borgo, 1976), among others.

In arachnids, the use of multisensory cues to make decisions is well known: whip spiders (Amblypygi) use both olfactory and visual cues for homing (Hebets et al., 2014), and female wolf spiders (Lycosidae) respond to males through perception of seismic and visual stimuli (Hebets \& Uetz, 1999, 2000; Hebets \& Papaj, 2005; Roberts, Taylor, \& Uetz, 2006; Uetz \& Roberts, 2002). Additionally, male lycosids have a better chance of being chosen as a mate if they use two distinct types of visual signals during courtship compared with one (Hebets \& Uetz, 2000), and salticids not only use highly variable multisensory courtship displays (e.g., Elias, Hebets, Hoy, Maddison, \& Mason, 2006; Girard, Kasumovic, \& Elias, 2011), but also appear to use multiple visual channels during courtship (Echeverri, Morehouse, \& Zurek, 2017).

Lycosids are able to visually assess patches with different prey density, choosing patches with higher prey density over those with less prey (Persons \& Uetz, 1998). In salticids, research suggests that prey assessment is extremely finely tuned. One example, alluded to above, is in Portia labiata, which can also evaluate the risk of dangerous prey. Spitting spiders (Scytodes sp.) are dangerous because they launch a sticky substance ("spit") from their mouths for both defense and predation. Therefore, when hunting Scytodes, P. labiata is liable to become Scytodes' own prey. However, P. labiata can discriminate non-dangerous female Scytodes carrying eggsacs in their mouthparts (which prevents them from spitting) from dangerous females without an eggsac, preferentially attacking Scytodes according to their risk of being harmed (i.e., attacking eggsac-carrying Scytodes) (Li \& Jackson, 2003). Perhaps even more impressive is Evarcha culicivora, a specialized salticid that preferentially feeds on blood-fed female Anopheles mosquitoes. By using visual and odor cues (Jackson et al., 2005; Cross \& Jackson, 2009b), E. culicivora can discriminate between several types of visually similar prey: male and female non-Anopheles mosquitoes, male Anopheles mosquitoes, and even between female 
Anopheles that have, and have not, fed on blood (Jackson et al., 2005; Nelson \& Jackson, 2006, 2012a,b). Prey preference and the predation strategy of these spiders is innate (Nelson et al., 2005). However, prey preference varies with the prior feeding condition: sated adult E. culicivora chooses Anopheles over Culex mosquitoes, and prefers sugar-fed female Anopheles over male Anopheles (Nelson \& Jackson, 2012a,b). Furthermore, juvenile E. culicivora innately prey upon Anopheles mosquitoes with a juvenile-specific predatory strategy, which consists of approaching the mosquito from behind, creeping under it, and biting underneath the thorax (Nelson et al., 2005). Once bitten, the mosquito flies away, with the spider still biting it, until the venom acts and the mosquito lands again, whereupon the spider begins eating. Selection of Anopheles over Culex and attacking the exact body part is crucial, as the spider attaches safely to the flying mosquito only under these conditions. Nevertheless, adults lose this specific predatory strategy, and simply pounce on the mosquito, as they weigh enough to stop it from flying away (Nelson et al., 2005). This predatory behavior suggests that juveniles use procedural knowledge mechanisms. However, flexibility in prey preference at all ages suggests prey assessment involving decision-making according to both hunger level and experience.

Directions for future work We argue that salticids can be used to specifically test for foraging-based hypotheses favoring cognitive ability by using predatory specialists and predatory generalists in cognitive tasks (i.e., testing ideas pertaining to the adaptive specialization, foraging niche, and clever foraging hypotheses), while often being able to control for phylogeny. For example, there are cases, such as in Evarcha, in which related species are either predatory specialists or generalists. We also argue that, again controlling for phylogeny by testing related species from different habitats, ecologically based hypotheses (e.g., ecological-intelligence hypothesis, adaptive-specialization hypothesis, spatial-cognition hypothesis, clever-foraging hypothesis) for selection for high-level cognition can be investigated. Finally, while most salticids are not social and therefore can be used to rule out ideas pertaining to level of sociality on the evolution of cognition, the very fact that there are a minority of species that are somewhat social (although it is rare to see cooperation in salticids, as is found in mammals) also permits this hypothesis to be examined.

Despite the fact that jumping spiders have tiny brains, they demonstrate a diverse variety of complex behavior that has been compared to that of mammals (e.g., Harland \& Jackson, 2000b; Land, 1974). Some of these complex behaviors are exhibited to various degrees of sophistication between species (and even within species, between the sexes and age categories). In some cases, we know that the morphology and physiology of the visual system of the animal can account for some of these differences (e.g., Cerveira et al., 2019). In turn, this suggests that there may well be differences in brain structure between the species, as it is known that the vast majority of the salticid "brain" (i.e., supra-esophageal ganglion) is involved in processing visual information (Long, 2020; Steinhoff, Sombke, Liedtke, Schneider, Harzsch, \& Uhl, 2017; Steinhoff, Uhl, Harzsch, \& Sombke, 2020). However, detailed analysis of all the visual centers of the salticid brain has only been performed on one species, Marpissa mucosa (Steinhoff et al., 2017, 2020).

A next step to understand the evolution of spatial cognition in salticids would be to determine if variation in cognitive ability correlates more closely with phylogeny or with the habitat complexity of the animal (see Table 1). Coupled with the fact that there are some "outlier" relatively social salticid species (Jackson, Nelson \& Salm, 2008; Nelson \& Jackson, 2009c), and that it is known that at least some salticids, such as Marpissa mucosa, reared in social environments outperform their siblings reared in isolation in learning tasks (Liedtke \& Schneider, 2017), the possibilities posed by the Salticidae in understanding selective factors, including sociality, favoring cognitive ability seem almost limitless.

Using key species from the same habitat that are both nonsocial (i.e., most salticids), and some that are relatively social, would permit an examination of the effect of sociality on cognitive ability, and this could have a phylogenetic lens applied to it. For example, in Kenya, Menemerus tropicus is a remarkably social species that lives in "nest complexes" that are literally built side-by-side and on top of one another (Jackson, 1986b). Menemerus is a large genus, and most species are not social, including other species from Kenya from similar habitats to that of Menemerus tropicus (Wesołowska, 1999), allowing for testing of cognitive ability in relation to phylogeny and sociality, while largely controlling for environmental differences. This type of work would be especially useful if both simple and complex habitats were found to house species that were both non-social and somewhat social. However, we know of no examples of relatively social salticids living in barren habitats.

Additionally, the effect of being reared in isolation or within a group of siblings can be parsed out. Liedtke and Schneider (2017) tentatively suggested that being reared with siblings has a stronger effect on learning tasks than being reared in the presence or absence of physical enrichment. If species from the same habitat that, as adults, differed in their level of sociality were tested after being reared in isolation or with their siblings, it would be possible to simultaneously consider the effects of social and of physical differences, both in rearing and in different or same habitat types. Indeed, as salticids are usually quite easy to rear in the laboratory, we could go one step further and look at genetic effects by rearing spiders with siblings and with non-siblings. Furthermore, now that the tools for examining the structure of spider brains exist 
(Steinhoff et al., 2017, 2020), the opportunity to further examine interspecific differences in the structure of salticid brains presents a wonderful new opportunity for research for key drivers underlying cognitive ability.

Acknowledgements The authors declare that they have no conflicts of interest. SA-A was supported by a College of Science Doctoral Scholarship from the University of Canterbury, New Zealand, and a student grant from the American Arachnological Society.

Open practices statement We comply with open access practices. As a review article, no original data are presented in this work.

\section{References}

Aguilar-Arguello, S., Gerhard, D., \& Nelson, X. J. (2019). Distance assessment of detours by jumping spiders. Current Zoology, 66, 263273. doi:https://doi.org/10.1093/cz/zoz044

Aguilar-Arguello, S., Gerhard, D., \& Nelson, X. J. (2020). Risk assessment and the use of novel shortcuts in spatial detouring tasks in jumping spiders. Behavioral Ecology, 30, 1488-1498. doi:https:// doi.org/10.1093/beheco/arz105

Ahmed, N. I., Thompson, C., Bolnick, D. I., \& Stuart, Y. E. (2017). Brain morphology of the threespine stickleback (Gasterosteus aculeatus) varies inconsistently with respect to habitat complexity: A test of the Clever Foraging Hypothesis. Ecology and Evolution, 7, 3372-3380. doi:https://doi.org/10.1002/ece3.2918

Barton, R. (1999). The evolutionary ecology of the primate brain. In P. C. Lee (Ed.), Comparative primate socioecology ( $1^{\text {st }}$ ed., pp. 167-203). Cambridge: Cambridge University Press.

Barton, R. A., \& Dunbar, R. I. M. (1997). Evolution of the social brain. In A. Whiten \& R. Byrne (Eds.), Machiavellian intelligence II (pp. 240-363). Cambridge: Cambridge University Press.

Bateson, P. (1983). Mate choice. Cambridge: Cambridge University Press.

Bauchot, R., Bauchot, M. L., Platel, R., \& Ridet, J. M. (1977). Brains of Hawaiian tropical fishes; brain size and evolution. Copeia, 1977, $42-$ 46. doi:https://doi.org/10.2307/1443502

Beauchamp, G., \& Fernández-Juricic. (2004). Is there a relationship between forebrain size and group size in birds? Evolutionary Ecology Research, 6, 833-842.

Biegler, R., McGregor, a., Krebs, J. R., \& Healy, S. D. (2001). A larger hippocampus is associated with longer-lasting spatial memory. Proceedings of the National Academy of Sciences USA, 98, 69416944. doi:https://doi.org/10.1073/pnas.121034798

Blest, A. D., O'Carroll, D. C., \& Carter, M. (1990). Comparative ultrastructure of layer I receptor mosaics in principal eyes of jumping spiders: The evolution of regular arrays of light guides. Cell Tissue Research, 262, 445-460. doi:https://doi.org/10.1007/BF00305241

Blumstein, D. T., \& Bouskila, A. (1996). Assessment and decision making in animals: A mechanistic model underlying behavioral flexibility can prevent ambiguity. Oikos, 77, 569-576. doi:https://doi.org/ $10.2307 / 3545948$

Byrne, R. W. (1997). The technical intelligence hypothesis: An additional evolutionary stimulus to intelligence? In A. Whiten \& R. W. Byrne (Eds.), Machiavellian intelligence II (pp. 289-311). Cambridge: Cambridge University Press.

Byrne, R. W. (2000). Evolution of primate cognition. Cognitive Science, 24, 543-570. doi:https://doi.org/10.1207/s15516709cog2403_8

Byrne, R. W. (2016). Pivot point: From social to technical abilities. Evolving Insight. Oxford: Oxford University Press.
Carducci, J., \& Jakob, E. M. (2000). Rearing environment affects behaviour of jumping spiders. Animal Behaviour, 59, 39-46. doi:https:// doi.org/10.1006/anbe.1999.1282

Castellucci, V., Pinsker, H., Kupfermann, I., \& Kandel, E. R. (1970). Neuronal mechanisms of habituation and dishabituation of the gillwithdrawal reflex in Aplysia. Science, 167, 1745. doi:https://doi.org/ 10.1126/science.167.3926.1745

Cerveira, A. M., Jackson, R. R., \& Guseinov, E. F. (2003). Stalking decisions of web-invading araneophagic jumping spiders from Australia, Azerbaijan, Israel, Kenya, Portugal, and Sri Lanka: The opportunistic smokescreen tactics of Brettus, Cocalus, Cyrba, and Portia. New Zealand Journal of Zoology, 30, 21-30. doi:https://doi. org/10.1080/03014223.2003.9518321

Cerveira, A. M., Jackson, R. R., \& Nelson, X. J. (2019). Dim-light vision in jumping spiders (Araneae, Salticidae): Identification of prey and rivals. Journal of Experimental Biology, 222, jeb198069. doi:https:// doi.org/10.1242/jeb.198069

Cheng, K. (2016). How animals think and feel: An introduction to nonhuman psychology. Santa Barbara, California: Greenwood.

Cheng, K., Middleton, E. J. T., \& Wehner, R. (2012). Vector-based and landmark-guided navigation in desert ants of the same species inhabiting landmark-free and landmark-rich environments. Journal of Experimental Biology, 215, 3169-3174. doi:https://doi.org/10. $1242 /$ jeb.070417

Cheng, K., Narendra, A., \& Wehner, R. (2006). Behavioral ecology of odometric memories in desert ants: Acquisition, retention, and integration. Behavioral Ecology, 17, 227-235. doi:https://doi.org/10. 1093/beheco/arj017

Chittka, L., \& Niven, J. (2009). Are bigger brains better? Current Biology, 19, R995-R1008. doi:https://doi.org/10.1016/j.cub.2009. 08.023

Chittka, L., Rossiter, S. J., Skorupski, P., \& Fernando, C. (2012). What is comparable in comparative cognition? Philosophical Transactions of the Royal Society London B, 367, 2677-2685. doi:https://doi.org/ 10.1098/rstb.2012.0215

Clarin, T. M. A., Ruczyński, I., Page, R. A., \& Siemers, B. M. (2013). Foraging ecology predicts learning performance in insectivorous bats. PLOS ONE, 8. doi:https://doi.org/10.1371/journal.pone. 0064823

Clutton-Brock, T. H., \& Harvey, P. H. (1977). Species differences in feeding and ranging behaviour in primates. In T. H. Clutton-Brock (Ed.), Primate ecology: Studies of feeding and ranging behaviour in lemurs, monkeys and apes. London: Academic Press.

Clutton-Brock, T. H., \& Harvey, P. H. (1980). Primates, brains and ecology. Journal of Zoology, 190, 309-323. doi:https://doi.org/10.1111/ j.1469-7998.1980.tb01430.x

Collett, T. S., \& Graham, P. (2004). Animal navigation: Path integration, visual landmarks and cognitive maps. Current Biology, 14, 475-477. doi:https://doi.org/10.1016/j.cub.2004.06.013

Costanzo, M. S., Bennett, N. C., \& Lutermann, H. (2009). Spatial learning and memory in African mole-rats: The role of sociality and sex. Physiology \& Behavior, 96, 128-134. doi:https://doi.org/10.1016/j. physbeh.2008.09.008

Cross, F. R., \& Jackson, R. R. (2009a). Odour-mediated response to plants by Evarcha culicivora, a blood-feeding jumping spider from East Africa. New Zealand Journal of Zoology, 36, 75-80.

Cross, F. R., \& Jackson, R. R. (2009b). Cross-modality priming of visual and olfactory selective attention by a spider that feeds indirectly on vertebrate blood. Journal of Experimental Biology, 212, 1869. doi: https://doi.org/10.1242/jeb.028126

Cross, F. R., \& Jackson, R. R. (2015). Solving a novel confinement problem by spartaeine salticids that are predisposed to solve problems in the context of predation. Animal Cognition, 18, 509-515. doi:https://doi.org/10.1007/s10071-014-0819-z 
Cross, F. R., \& Jackson, R. R. (2016). The execution of planned detours by spider-eating predators. Journal of the Experimental Analysis of Behavior, 105, 194-210. doi:https://doi.org/10.1002/jeab.189

Cross, F. R., \& Jackson, R. R. (2019). Portia's capacity to decide whether a detour is necessary. Journal of Experimental Biology, 222, jeb203463. doi:https://doi.org/10.1242/jeb.203463

Crystal, J. D. (2018). Animal models of episodic memory. Comparative Cognition \& Behavior Reviews, 13, 105-122. doi:https://doi.org/10. 3819/CCBR.2018.130012

Dall, S. R. X., Giraldeau, L.-A., Olsson, O., McNamara, J. M., \& Stephens, D. W. (2005). Information and its use by animals in evolutionary ecology. Trends in Ecology \& Evolution, 20, 187-193. doi: https://doi.org/10.1016/j.tree.2005.01.010

Dall, S. R. X., \& Johnstone, R. A. (2002). Managing uncertainty: Information and insurance under the risk of starvation. Philosophical Transactions of the Royal Society London B, 357, 1519-1526. doi:https://doi.org/10.1098/rstb.2002.1061

Dick, J. T. A., \& Elwood, R. W. (1989). Assessments and decisions during mate choice in Gammarus Pulex (Amphipoda). Behaviour, 109, 235-245. doi:https://doi.org/10.1163/156853989X00259

Dowds, B. M., \& Elwood, R. W. (1983). Shell wars: Assessment strategies and the timing of decisions in hermit crab shell fights. Behaviour, 85,1-24. doi:https://doi.org/10.1163/ 156853983X00011

du Toit, L., Bennett, N. C., Nickless, A., \& Whiting, M. J. (2012). Influence of spatial environment on maze learning in an African mole-rat. Animal Cognition, 15, 797-806. doi:https://doi.org/10. 1007/s10071-012-0503-0

Dukas, R. (2002). Behavioural and ecological consequences of limited attention. Philosophical Transactions of the Royal Society London B, 357, 1539-1547. doi:https://doi.org/10.1098/rstb.2002.1063

Dukas, R. (2008). Evolutionary biology of animal cognition. Annual Review of Entomology, 53, 145-3160. doi:https://doi.org/10.1146/ annurev.ento.53.103106.093343

Dunbar, R. I. M. (1992). Neocortex size as a constraint on group size in primates. Journal of Human Evolution, 22, 469-493.

Dunbar, R. I. M. (1998). The social brain hypothesis. Evolutionary Anthropology, 6, 178-190. doi:https://doi.org/10.1002/(SICI)15206505(1998)6:5<178::AID-EVAN5>3.0.CO;2-8

Dunbar, R. I. M. (2009). The social brain hypothesis and its implications for social evolution. Annals of Human Biology, 36, 562-572. doi: https://doi.org/10.1080/03014460902960289

Dunbar, R. I. M., \& Bever, J. (1998). Neocortex size predicts group size in carnivores and some insectivores. Ethology, 104, 695-708. doi: https://doi.org/10.1111/j.1439-0310.1998.tb00103.x

Eberhard, W. G. (2007). Miniaturized orb-weaving spiders: behavioural precision is not limited by small size. Proceedings of the Royal Society of London B, 274, 2203-2209. doi:https://doi.org/10.1098/ rspb.2007.0675

Eberhard, W. G., \& Wcislo, W. T. (2011). Grade changes in brain-body allometry: Morphological and behavioural correlates of brain size in miniature spiders, insects and other invertebrates. Advances in Insect Physiology, 40, 155-214. doi:https://doi.org/10.1016/B978-0-12387668-3.00004-0

Echeverri, S. A., Morehouse, N. I., \& Zurek, D. B. (2017). Control of signaling alignment during the dynamic courtship display of a jumping spider. Behavioral Ecology, 28, 1445-1453. doi:https:// doi.org/10.1093/beheco/arx107

Edwards, G. B., \& Jackson, R. R. (1993). Use of prey-specific predatory behaviour by North American jumping spiders (Araneae, Salticidae) of the genus Phidippus. Journal of Zoology, 229, 709-716. doi: https://doi.org/10.1111/j.1469-7998.1993.tb02666.x

Edwards, G. B., \& Jackson, R. R. (1994). The role of experience in the development of predatory behaviour in Phidippus regius, a jumping spider (Araneae, Salticidae) from Florida. New Zealand Journal of
Zoology, 21, 269-277. doi:https://doi.org/10.1080/03014223.1994. 9517994

Eisenberg, J. F., \& Wilson, D. E. (1978). Relative brain size and feeding strategies in the Chiroptera. Evolution, 32, 740-751. doi:https://doi. org/10.2307/2407489

Elias, D.O., Hebets, E.A., Hoy, R.R., Maddison, W.P., Mason, A.C., 2006. Regional seismic song differences in sky island populations of the jumping spider Habronattus pugillis Griswold (Araneae, Salticidae). Journal of Arachnology, 34, 545-556.

Falk, H., Biebach, H., \& Krebs, J. R. (1992). Learning a time-place pattern of food availability: A comparison between an insectivorous and a granivorous weaver species (Ploceus bicolor and Euplectes hordeaceus). Behavioral Ecology \& Sociobiology, 31, 9-15. doi: https://doi.org/10.1007/BF00167811

Farris, S. M. (2016). Insect societies and the social brain. Current Opinion in Insect Science, 15, 1-8. doi:https://doi.org/10.1016/j.cois.2016. 01.010

Finarelli, J. A., \& Flynn, J. J. (2009). Brain-size evolution and sociality in Carnivora. Proceedings of the National Academy of Sciences USA, 106, 9345-9349. doi:https://doi.org/10.1073/pnas.0901780106

Foelix, R. F. (2011). Biology of spiders (Third). New York: Oxford University Press.

Forster, L. M. (1982). Vision and prey-catching strategies in jumping spiders. American Scientist, 70, 165-175.

Freed, A. N. (1984). Foraging behaviour in the jumping spider Phidippus audax: bases for selectivity. Journal of Zoology, 203, 49-61. doi: https://doi.org/10.1111/j.1469-7998.1984.tb06043.x

Frick, K. M., \& Fernandez, S. M. (2003). Enrichment enhances spatial memory and increases synaptophysin levels in aged female mice. Neurobiology of Aging, 24, 615-626. doi:https://doi.org/10.1016/ S0197-4580(02)00138-0

Frick, K. M., Stearns, N. A., Pan, J.-Y., \& Berger-Sweeney, J. (2003). Effects of environmental enrichment on spatial memory and neurochemistry in middle-aged mice. Learning \& Memory, 10, 187-198. doi:https://doi.org/10.1101/lm.50703

Gardner, B. T. (1965). Observations on three species of Phidippus jumping spiders (Araneae: Salticidae). Psyche: A journal of Entomology, 72, 133-147. doi:https://doi.org/10.1155/1965/91416

Gibson, B. M., Wasserman, E. A., \& Kamil, A. C. (2007). Pigeons and people select efficient routes when solving a one-way "traveling salesperson" task. Journal of Experimental Psychology: Animal Behavior Processes, 33, 244-261. doi:https://doi.org/10.1037/ 0097-7403.33.3.244

Girard, M. B., Kasumovic, M. M., \& Elias, D. O. (2011). Multi-modal courtship in the peacock spider, Maratus volans (O.P.-Cambridge, 1874). PLoS ONE 6(9): e25390. doi:https://doi.org/10.1371/ journal.pone. 0025390

Gittleman, J. L. (1986). Carnivore brain size, behavioral ecology, and phylogeny. Journal of Mammalogy, 67, 23-36. doi:https://doi.org/ $10.2307 / 1380998$

Givens, R. P. (1978). Dimorphic foraging strategies of a salticid spider (Phidippus audax). Ecology, 59, 309-321.

Görner, P., \& Claas, B. (1985). Homing behavior and orientation in the funnel-web spider, Agelena labyrinthica Clerck. In F. G. Barth (Ed.), Neurobiology of arachnids (pp. 275-297). Berlin, Heidelberg: Springer Berlin Heidelberg.

Guseinov, E. F., Cerveira, A. M., \& Jackson, R. R. (2004). The predatory strategy, natural diet, and life cycle of Cyrba algerina, an araneophagic jumping spider (Salticidae: Spartaeinae) from Azerbaijan. New Zealand Journal of Zoology, 31, 291-303. doi: https://doi.org/10.1080/03014223.2004.9518382

Halliday, T. R. (1983). The study of mate choice. In P. Bateson (Ed.), Mate choice (pp. 3-33). Cambridge: Cambridge University Press.

Hampton, R. R., \& Shettleworth, S. J. (1996). Hippocampal lesions impair memory for location but not color in passerine birds. Behavioral 
Neuroscience, 110, 831-835. doi:https://doi.org/10.1037/07357044.110.4.831

Harland, D. P., \& Jackson, R. R. (2000a). Cues by which Portia fimbriata, an araneophagic jumping spider, distinguishes jumpingspider prey from other prey. Journal of Experimental Biology, 203, 3485-3494.

Harland, D. P., \& Jackson, R. R. (2000b). 'Eight-legged cats' and how they see: A review of recent research on jumping spiders (Araneae: Salticidae). Cimbebasia, 16, 231-240.

Harland, D. P., \& Jackson, R. R. (2001). Prey classification by Portia fimbriata, a salticid spider that specializes at preying on other salticids: species that elicit cryptic stalking. Journal of Zoology, $255,445-460$.

Harland, D. P., Li, D., \& Jackson, R. R. (2012). How jumping spiders see the world. In O. F. Lazareva, T. Shimizu, \& E. A. Wasserman (Eds.), How animals see the World: Comparative behavior, biology, and evolution of vision (First, pp. 133-163). New York: Oxford University Press.

Harvey, P. H., Clutton-Brock, T. H., \& Mace, G. M. (1980). Brain size and ecology in small mammals and primates. Proceedings of the National Academy of Sciences USA, 77, 4387-4389. doi:https:// doi.org/10.1073/pnas.77.7.4387

Harvey, P. H., \& Krebs, J. R. (1990). Comparing brains. Science, 249, 140-146. doi:https://doi.org/10.1126/science.2196673

Hazlett, B. A., \& McLay, C. (2005). Responses to predation risk: alternative strategies in the crab Heterozius rotundifrons. Animal Behaviour, 69, 967-972. doi:https://doi.org/10.1016/j.anbehav. 2004.06.028

Hebets, E. A., Aceves-Aparicio, A., Aguilar-Arguello, S., Bingman, V. P., Escalante, I., Gering, E. J., Nelsen, D. R., Rivera, J., SánchezRuiz, J. A., Segura-Hernández, L., Settepani, V., Wiegmann, D. D., \& Stafstrom, J. (2014). Multimodal sensory reliance in the nocturnal homing of the amblypygid Phrynus pseudoparvulus (Class Arachnida, Order Amblypygi)? Behavioral Processes, 108, 123130. doi:https://doi.org/10.1016/j.beproc.2014.09.014

Hebets, E. A., \& Papaj, D. R. (2005). Complex signal function: Developing a framework of testable hypotheses. Behavioral Ecology \& Sociobiology, 57, 197-214. doi:https://doi.org/10.1007/ s00265-004-0865-7

Hebets, E. A., \& Uetz, G. W. (1999). Female responses to isolated signals from multimodal male courtship displays in the wolf spider genus Schizocosa (Araneae: Lycosidae). Animal Behaviour, 57, 865-872. doi:https://doi.org/10.1006/anbe.1998.1048

Hebets, E. A., \& Uetz, G. W. (2000). Leg ornamentation and the efficacy of courtship display in four species of wolf spider (Araneae: Lycosidae). Behavioral Ecology \& Sociobiology, 47, 280-286. doi: https://doi.org/10.1007/s002650050667

Heil, K. H. (1936). Beiträge zur Physiologie und Psychologie der springspinnen. Zeitschrift für vergleichende Physiologie, 23, 1-25. doi:https://doi.org/10.1007/BF00340080

Heinze, S., Narendra, A., \& Cheung, A. (2018). Principles of insect path integration. Current Biology, 28, R1043-R1058. doi:https://doi.org/ 10.1016/j.cub.2018.04.058

Hill, D. E. (1979). Orientation by jumping spiders of the genus Phidippus (Araneae: Salticidae) during the pursuit of prey. Behavioral Ecology \& Sociobiology, 5, 301-322. doi:https://doi.org/10.1007/ BF00293678

Hill, D. E. (2007). Use of location (relative direction and distance) information by jumping spiders (Araneae, Salticidae, Phidippus) during movement toward prey and other sighted objectives. Peckhamia, 83, $1-72$.

Hoefler, C. D., \& Jakob, E. M. (2006). Jumping spiders in space: Movement patterns, nest site fidelity and the use of beacons. Animal Behaviour, 71, 109-116. doi:https://doi.org/10.1016/j. anbehav.2005.03.033
Hölldobler, B. (1999). Multimodal signals in ant communication. Journal of Comparative Physiology A, 184, 129-141.

Honkanen, A., Adden, A., da Silva Freitas, J., \& Heinze, S. (2019). The insect central complex and the neural basis of navigational strategies. The Journal of Experimental Biology, 222, jeb188854. doi: https://doi.org/10.1242/jeb.188854

Jackson, R. R. (1977). Prey of the jumping spider Phidippus johnsoni (Araneae: Salticidae). Journal of Arachnology, 5, 145-149.

Jackson, R. R. (1979). Nests of Phidippus johnsoni (Araneae, Salticidae): Characteristics, pattern of occupation, and function. Journal of Arachnology, 7, 47-58.

Jackson, R. R. (1986a). The biology of ant-like jumping spiders (Araneae, Salticidae): prey and predatory behaviour of Myrmarachne with particular attention to M. lupata from Queensland. Zoological Journal of the Linnean Society, 88, 179190. doi:https://doi.org/10.1111/j.1096-3642.1986.tb01186.x

Jackson, R.R. (1986b). Communal jumping spiders (Araneae: Salticidae) from Kenya: Interspecific nest complexes, cohabitation with webbuilding spiders, and interspecific interactions. New Zealand Journal of Zoology, 13, 13-26. doi:https://doi.org/10.1080/ 03014223.1986 .10422643

Jackson, R. R. (1990a). Predatory versatility and intraspecific interactions of Cyrba algerina and Cyrba ocellata, web-invading spartaeine jumping spiders (Araneae: Salticidae). New Zealand Journal of Zoology, 17, 157-168. doi:https://doi.org/10.1080/03014223.1990. 10422593

Jackson, R. R. (1990b). Predatory and nesting behaviour of Cocalus gibbosus, a spartaeine jumping spider (Araneae: Salticidae) from Queensland. New Zealand Journal of Zoology, 17, 483-490. doi: https://doi.org/10.1080/03014223.1990.10422947

Jackson, R. R. (1990c). Predatory and silk utilisation behaviour of Gelotia sp. indet. (Araneae: Salticidae: Spartaeinae), a webinvading aggressive mimic from Sri Lanka. New Zealand Journal of Zoology, 17, 475-482. doi:https://doi.org/10.1080/03014223. 1990.10422946

Jackson, R. R. (1990d). Ambush predatory behaviour of Phaeacius malayensis and Phaeacius sp. indet., spartaeine jumping spiders (Araneae: Salticidae) from tropical Asia. New Zealand Journal of Zoology, 17, 491-498. doi:https://doi.org/10.1080/03014223.1990. 10422948

Jackson, R. R., \& Blest, A. D. (1982). The biology of Portia fimbriata, a web-building jumping spider (Araneae, Salticidae) from Queensland: Utilization of webs and predatory versatility. Journal of Zoology, 196, 255-293. doi:https://doi.org/10.1111/j.1469-7998. 1982.tb03504.x

Jackson, R. R., Carter, C. M., Tarsitano, M. S. (2001). Trial-and-error solving of a confinement problem by a jumping spider, Portia fimbriata. Behaviour, 138, 1215-1234. doi:https://doi.org/10.2307/ 4535886

Jackson, R. R., \& Cross, F. R. (2011). Spider cognition. Advances in Insect Physiology, 41, 115-174.

Jackson, R. R., Cross, F. R., \& Carter, C. M. (2006). Geographic variation in a spider's ability to solve a confinement problem by trial and error. International Journal of Comparative Psychology, 19, 282296.

Jackson, R. R., \& Hallas, S. E. A. (1986a). Capture efficiencies of webbuilding jumping spiders (Araneae, Salticidae): Is the jack-of-alltrades the master of none. Journal of Zoology, 209, 1-7.

Jackson, R. R., \& Hallas, S. E. A. (1986b). Comparative biology of Portia africana, P. albimana, P. fimbriata, P. labiata, and $P$. schultzi, araneophagic web-building jumping spiders (Araneae: Salticidae): Utilisation of silk, predatory versatility, and intraspecific interactions. New Zealand Journal of Zoology, 13, 423-489. doi: https://doi.org/10.1080/03014223.1986.10422978

Jackson, R. R., \& Nelson, X. J. (2011). Reliance on trial and error signal derivation by Portia africana, an araneophagic jumping spider from 
East Africa. Journal of Ethology, 29, 301-307. doi:https://doi.org/ 10.1007/s10164-010-0258-5

Jackson, R. R., Nelson, X. J., \& Salm, K. (2008). The natural history of Myrmarachne melanotarsa, a social ant-mimicking jumping spider. New Zealand Journal of Zoology, 35, 225-235. doi:https://doi.org/ 10.1080/03014220809510118

Jackson, R. R., Nelson, X. J., \& Sune, G.O. (2005). A spider that feeds indirectly on vertebrate blood by choosing female mosquitoes as prey. Proceedings of the National Academy of Science USA, 102, 15155-15160. doi:https://doi.org/10.1073/pnas.0507398102

Jackson, R. R., \& Pollard, S. D. (1996). Predatory behavior of jumping spiders. Annual Review of Entomology, 41, 287-308. doi:https://doi. org/10.1146/annurev.en.41.010196.001443

Jackson, R. R., Pollard, S. D., Li, D., \& Fijn, N. (2002). Interpopulation variation in the risk-related decisions of Portia labiata, an araneophagic jumping spider (Araneae, Salticidae), during predatory sequences with spitting spiders. Animal Cognition, 5, 215-223. doi:https://doi.org/10.1007/s10071-002-0150-y

Jackson, R. R., \& Wilcox, R. S. (1990). Aggressive mimicry, preyspecific predatory behaviour and predator recognition in the predator-prey interactions of Portia fimbriata and Euryattus sp., jumping spiders from Queensland. Behavioral Ecology \& Sociobiology, 26, 111-119. doi:https://doi.org/10.1007/ BF00171580

Jackson, R. R., \& Wilcox, S. R. (1993). Observations in nature of detouring behaviour by Portia fimbriata, a web-invading aggressive mimic jumping spider from Queensland. Journal of Zoology, 230, 135-139. doi:https://doi.org/10.1111/j.1469-7998.1993.tb02677.x

Jackson, R. R., \& Willey, M. B. (1994). The comparative study of the predatory behaviour of Myrmarachne, ant-like jumping spiders (Araneae: Salticidae). Zoological Journal of the Linnean Society, 110, 77-102. doi:https://doi.org/10.1111/j.1096-3642.1994. tb01472.x

Jakob, E. M., \& Long, S. M. (2016). How (not) to train your spider: successful and unsuccessful methods for studying learning. New Zealand Journal of Zoology, 43, 112-126. doi:https://doi.org/10. 1080/03014223.2015.1127263

Jakob, E. M., Skow, C. D., \& Long, S. M. (2011). Plasticity, learning and cognition. In M. E. Herberstein (Ed.), Spider behaviour: Flexibility and versatility (pp. 307-347). New York: Cambridge University Press.

Jakob, E. M., Skow, C. D., Popson Haberman, M., \& Plourde, A. (2007). Jumping spiders associate food with color cues in a T-maze. Journal of Arachnology, 35, 487-492.

Joffe, T. H., \& Dunbar, R. I. M. (1997). Visual and socio-cognitive information processing in primate brain evolution. Proceedings of the Royal Society of London B, 264, 1303-1307. doi:https://doi.org/ 10.1098/rspb.1997.0180

Johnson, K., \& Borgo, P. M. (1976). Patterned perching behavior in two Callophrys (Mitoura)(Lycaenidae). Journal of the Lepidopterists' Society, 30, 169-183.

Kamhi, J. F., Gronenberg, W., Robson, S. K. A., \& Traniello, J. F. A. (2016) Social complexity influences brain investment and neural operation costs in ants. Proceedings of the Royal Society of London B, 283, 20161949. doi:https://doi.org/10.1098/rspb.2016. 1949

Kim, I. S., \& Dickinson, M. H. (2017). Idiothetic path integration in the fruit fly Drosophila melanogaster. Current Biology, 27, 2227-2238. doi:https://doi.org/10.1016/j.cub.2017.06.026

Krebs, J. R. (1990). Food-storing birds: Adaptive specialization in brain and behaviour? Philosophical Transactions of the Royal Society London B, 329, 153-160. doi:https://doi.org/10.1098/rstb.1990. 0160

Krebs, J. R., Sherry, D. F., Healy, S. D., Perry, V. H., \& Vaccarino, A. L. (1989). Hippocampal specialization of food-storing birds.
Proceedings of the National Academy of Sciences USA, 86, 13881392. doi:https://doi.org/10.1073/pnas.86.4.1388

Land, M. F. (1969a). Structure of the retinae of the principal eyes of jumping spiders (Salticidae: Dendryphantinae) in relation to visual optics. Journal of Experimental Biology, 51, 443-470.

Land, M. F. (1969b). Movements of the retinae of jumping spiders (Salticidae: Dendryphantinae) in response to visual stimuli. Journal of Experimental Biology, 51, 471-493.

Land, M. F. (1974). A comparison of the visual behaviour of a predatory arthropod with that of a mammal. In C. A. G. Wiersma (Ed.), Invertebrate neurons and behavior. Cambridge: MIT Press, pp. 411-418.

Land, M. F. (1981). Optics and vision in invertebrates. In H. Autrum (Ed.), Comparative physiology and evolution of vision in invertebrates (Vol. VII, pp. 471-592). Berlin: Handbook of sensory physiology.

Land, M. F. (1985a). The morphology and optics of spider eyes. In F. G. Barth (Ed.), Neurobiology of arachnids (pp. 53-78). Berlin, Heidelberg: Springer Berlin Heidelberg.

Land, M. F. (1985b). Fields of view of the eyes of primitive jumping spiders. Journal of Experimental Biology, 119, 381-384.

Land, M. F. (2005). The optical structures of animal eyes. Current Biology, 15, R319-R323. doi:https://doi.org/10.1016/j.cub.2005. 04.041

Land, M. F., \& Fernald, R. D. (1992). The evolution of eyes. Annual Reviews in Neuroscience, 15, 1-29. doi:https://doi.org/10.1146/ annurev.ne.15.030192.000245

Li, D., \& Jackson, R. R. (1996). Prey preferences of Portia fimbriata, an araneophagic, web- building jumping spider (Araneae: Salticidae) from Queensland. Journal of Insect Behavior, 9, 613-642. doi: https://doi.org/10.1007/BF02213884

Li, D., \& Jackson, R. R. (2003). A predator's preference for egg-carrying prey: a novel cost of parental care. Behavioral Ecology \& Sociobiology, 55, 129-136. doi:https://doi.org/10.1007/s00265003-0689-x

Liedtke, J., Redekop, D., Schneider, J. M., \& Schuett, W. (2015). Early environmental conditions shape personality types in a jumping spider. Frontiers in Ecology \& Evolution, 3, 134. doi:https://doi.org/10. 3389/fevo.2015.00134

Liedtke, J., \& Schneider, J. M. (2014). Association and reversal learning abilities in a jumping spider. Behavioural Processes, 103, 192-198. doi:https://doi.org/10.1016/j.beproc.2013.12.015

Liedtke, J., \& Schneider, J. M. (2017). Social makes smart: Rearing conditions affect learning and social behaviour in jumping spiders. Animal Cognition, 20, 1093-1106. doi:https://doi.org/10.1007/ s10071-017-1125-3

Lihoreau, M., Latty, T., \& Chittka L. (2012). An exploration of the social brain hypothesis in insects. Frontiers in Physiology, 3, 442. doi: https://doi.org/10.3389/fphys.2012.00442

Lima, S. L., \& Dill, L. M. (1990). Behavioral decisions made under the risk of predation: A review and prospectus. Canadian Journal of Zoology, 68, 619-640. doi:https://doi.org/10.1139/z90-092

Long, S. M. (2020). Variations on a theme: Morphological variation in the secondary eye visual pathway across the order of Araneae. Journal of Comparative Neurology, In Press doi:https://doi.org/10. $1002 /$ cne.24945.

Mace, G. M., Harvey, P. H., \& Clutton-Brock, T. H. (1981). Brain size and ecology in small mammals. Journal of Zoology, 193, 333-354. doi:https://doi.org/10.1111/j.1469-7998.1981.tb03449.x

MacLean, E. L., Barrickman, N. L., Johnson, E. M., \& Wall, C. E. (2009). Sociality, ecology, and relative brain size in lemurs. Journal of Human Evolution, 56, 471-478. doi:https://doi.org/10.1016/j. jhevol.2008.12.005

Maddison, W. P., Evans, S. C., Hamilton, C. A., Bond, J. E., Lemmon, A. R., \& Lemmon, E. M. (2017). A genome-wide phylogeny of jumping spiders (Araneae, Salticidae), using anchored hybrid 
enrichment. ZooKeys, 695, 89-101. doi:https://doi.org/10.3897/ zookeys.695.13852

Maddison, W. P., Li, D., Bodner, M., Zhang, J., Xu, X., Liu, Q., \& Liu, F. (2014). The deep phylogeny of jumping spiders (Araneae, Salticidae). ZooKeys, 87, 57-87. doi:https://doi.org/10.3897/ zookeys.440.7891

Marino, L. (1996). What can dolphins tell us about primate evolution? Evolutionary Anthropology, 5, 81-86. doi:https://doi.org/10.1002/ (SICI)1520-6505(1996)5:3<81::AID-EVAN3>3.0.CO;2-Z

Martin, C. W., Fodrie, F. J., Heck, K. L., \& Mattila, J. (2010). Differential habitat use and antipredator response of juvenile roach (Rutilus rutilus) to olfactory and visual cues from multiple predators. Oecologia, 162, 893-902. doi:https://doi.org/10.1007/s00442-0101564-x

Menzel, C. R. (1999). Unprompted recall and reporting of hidden objects by a chimpanzee (Pan troglodytes) after extended delays. Journal of Comparative Psychology, 113, 426-434. doi:https://doi.org/10. 1037/0735-7036.113.4.426

Menzel, R. (2013). Learning, memory, and cognition: Animal perspectives. In C. G. Galizia \& P.-M. Lledo (Eds.), Neurosciences - from molecule to behavior: A university textbook (pp. 629-653). Berlin, Heidelberg: Springer Berlin Heidelberg.

Menzel, R., Greggers, U., Smith, A., Berger, S., Brandt, R., Brunke, S., Bundrock, G., Plu, T., Schaupp, F., Schu, E., Stach, S., Stindt, J., Stollhoff, N., \& Watzl, S. (2005). Honey bees navigate according to a map-like spatial memory. Proceedings of the National Academy of Sciences USA, 102, 3040-3045. doi:https://doi.org/10.1073/pnas. 0408550102

Mery, F. (2013). Natural variation in learning and memory. Current Opinion in Neurobiology, 23, 52-56. doi:https://doi.org/10.1016/j. conb.2012.09.001

Mery, F., \& Kawecki, T. J. (2002). Experimental evolution of learning ability in fruit flies. Proceedings of the National Academy of Sciences USA, 99, 14274-14279. doi:https://doi.org/10.1073/pnas. 222371199

Milton, K. (1981). Distribution patterns of tropical plant foods as an evolutionary stimulus to primate mental development. American Anthropologist, 83, 534-548. doi:https://doi.org/10.1525/aa.1981. 83.3.02a00020

Moller, P., \& Görner, P. (1994). Homing by path integration in the spider Agelena labyrinthica Clerck. Journal of Comparative Physiology A, 174, 221-229. doi:https://doi.org/10.1007/BF00193788

Mooney, K. A., \& Haloin, J. R. (2009). Nest site fidelity in Paraphidippus aurantia (Salticidae). Journal of Arachnology, 34, 241-243. doi:https://doi.org/10.1636/S03-41.1

Nagata, T., Koyanagi, M., Tsukamoto, H., Saeki, S., Isono, K., Shichida, Y., Tokunaga, F., Kinoshita, M., Arikawa, K. and Terakita, A. (2012). Depth perception from image defocus in a jumping spider. Science, 335, 469-471. doi:https://doi.org/10.1126/science.1211667

Nakamura, T., \& Yamashita, S. (2000). Learning and discrimination of colored papers in jumping spiders (Araneae, Salticidae). Journal of Comparative Physiology A, 186, 897-901. doi:https://doi.org/10. $1007 / \mathrm{s} 003590000143$

Narendra, A. (2007). Homing strategies of the Australian desert ant Melophorus bagoti II. Interaction of the path integrator with visual cue information. Journal of Experimental Biology, 210, 1804-1812. doi:https://doi.org/10.1242/jeb.02769

Narendra, A., Cheng, K., \& Wehner, R. (2007). Acquiring, retaining and integrating memories of the outbound distance in the Australian desert ant Melophorus bagoti. Journal of Experimental Biology, 210, 570-577. doi:https://doi.org/10.1242/jeb.02678

Nelson, X. J., \& Jackson, R. (2006). A predator from East Africa that chooses malaria vectors as preferred prey. PLoS ONE, 1, e132. doi: https://doi.org/10.1371/journal.pone.0000132

Nelson, X. J., \& Jackson, R. R. (2009a). Prey classification by an araneophagic ant-like jumping spider (Araneae: Salticidae).
Journal of Zoology, 279, 173-179. doi:https://doi.org/10.1111/j. 1469-7998.2009.00602.x

Nelson, X. J., \& Jackson, R. R. (2009b). The influence of ants on the mating strategy of a myrmecophilic jumping spider (Araneae, Salticidae). Journal of Natural History, 43, 713-735. doi:https:// doi.org/10.1080/00222930802610469

Nelson, X. J., \& Jackson, R. R. (2009c). Collective Batesian mimicry of ant groups by aggregating spiders. Animal Behaviour, 78, 123-129. doi:https://doi.org/10.1016/j.anbehav.2009.04.005

Nelson, X. J., \& Jackson, R. R. (2012a). Fine tuning of vision-based preychoice decisions by a predator that targets malaria vectors. Journal of Arachnology, 40, 23-33. doi:https://doi.org/10.1636/Hill-6-1.1

Nelson, X. J., \& Jackson, R. R. (2012b). The discerning predator: Decision rules underlying prey classification by a mosquito-eating jumping spider. Journal of Experimental Biology, 215, 2255-2261. doi:https://doi.org/10.1242/jeb.069609

Nelson, X. J., \& Jackson, R. R. (2013). Hunger-driven response by a nectar-eating jumping spider to specific phytochemicals. Chemoecology, 23, 149-153. doi:https://doi.org/10.1007/s00049013-0130-5

Nelson, X. J., \& Jackson, R. R. (2014). Timid spider uses odor and visual cues to actively select protected nesting sites near ants. Behavioral Ecology \& Sociobiology, 68, 773-780. doi:https://doi.org/10.1007/ s00265-014-1690-2

Nelson, X. J., Jackson, R. R., \& Sune, G. (2005). Use of Anopheles specific prey-capture behavior by the small juveniles of Evarcha culicivora, a mosquito-eating jumping spider. Journal of Arachnology, 33, 541-548. https://doi.org/10.1636/05-3.1

Nilsson, M., Perfilieva, E., Johansson, U., Orwar, O., \& Eriksson, P. S. (1999). Enriched environment increases neurogenesis in the adult rat dentate gyrus and improves spatial memory. Journal of Neurobiology, 39, 569-578. doi:https://doi.org/10.1002/(SICI) 1097-4695(19990615)39:4<569::AID-NEU10>3.0.CO;2-F

Nørgaard, T., Henschel, J. R., \& Wehner, R. (2003). Long-distance navigation in the wandering desert spider Leucorchestris arenicola: Can the slope of the dune surface provide a compass cue? Journal of Comparative Physiology A, 189, 801-809. doi:https://doi.org/10. 1007/s00359-003-0455-6

Ortega-Escobar, J. (2002). Evidence that the wolf spider Lycosa tarentula (Araneae: Lycosidae) needs visual input for path integration. Journal of Arachnology, 30, 481-486. doi:https://doi.org/10.1636/ 0161-8202(2002)030[0481:ETTWSL]2.0.CO;2

Ortega-Escobar, J. (2006). Role of the anterior lateral eyes of the wolf spider Lycosa tarentula (Araneae, Lycosidae) during path integration. Journal of Arachnology, 34, 51-61. doi:https://doi.org/10. 1636/S04-103.1

Park P. J., Bell M. A. (2010). Variation of telencephalon morphology of the threespine stickleback (Gasterosteus aculeatus) in relation to inferred ecology. Journal of Evolutionary Biology, 23, 1261-1277. doi:https://doi.org/10.1111/j.1420-9101.2010.01987.x

Parker, S. T., \& Gibson, K. R. (1977). Object manipulation, tool use and sensorimotor intelligence as feeding adaptations in Cebus monkeys and great apes. Journal of Human Evolution, 6, 623-641. doi:https:// doi.org/10.1016/S0047-2484(77)80135-8

Partan, S., \& Marler, P. (1999). Communication goes multimodal. Science, 283, 1272-1273. doi:https://doi.org/10.1126/science.283. 5406.1272

Partan, S. R., Larco, C. P., \& Owens, M. J. (2009). Wild tree squirrels respond with multisensory enhancement to conspecific robot alarm behaviour. Animal Behaviour, 77, 1127-1135. doi:https://doi.org/ 10.1016/j.anbehav.2008.12.029

Partridge, L. (1978). Habitat selection. In J. R. Krebs \& N. B. Davies (Eds.), Behavioural ecology (pp. 351-376). Oxford: Blackwell Scientific.

Peckmezian, T., \& Taylor, P. W. (2015a). A virtual reality paradigm for the study of visually mediated behaviour and cognition in spiders. 
Animal Behaviour, 107, 87-95. doi:https://doi.org/10.1016/j. anbehav.2015.06.018

Peckmezian, T., \& Taylor, P. W. (2015b). Electric shock for aversion training of jumping spiders: Towards an arachnid model of avoidance learning. Behavioural Processes, 113, 99-104. doi:https://doi. org/10.1016/j.beproc.2015.01.015

Peckmezian, T., \& Taylor, P. W. (2017). Place avoidance learning and memory in a jumping spider. Animal Cognition, 20, 275-284. doi: https://doi.org/10.1007/s10071-016-1048-4

Persons, M. H., \& Uetz, G. W. (1998). Presampling sensory information and prey density assessment by wolf spiders (Araneae, Lycosidae). Behavioral Ecology, 9, 360-366. doi:https://doi.org/10.1093/ beheco/9.4.360

Pirlot, P., \& Stephan, H. (1970). Encephalization in Chiroptera. Canadian Journal of Zoology, 48, 433-444. doi:https://doi.org/10.1139/z70075

Plomin, R., DeFries, J. C., Knopik, V. S., \& Neiderhiser, J. M. (2013). Behavioral genetics (Sixth). New York: New Publishers.

Pravosudov, V. V., \& Roth II, T. C. (2013). Cognitive ecology of food hoarding: the evolution of spatial memory and the hippocampus. Annual Review of Ecology, Evolution, and Systematics, 44, 173193. doi:https://doi.org/10.1146/annurev-ecolsys-110512-135904

Rampon, C., Tang, Y.-P., Goodhouse, J., Shimizu, E., Kyin, M., \& Tsien, J. Z. (2000). Enrichment induces structural changes and recovery from nonspatial memory deficits in CA1 NMDAR1-knockout mice. Nature Neuroscience, 3, 238-244. http://www.nature.com/neuro/ journal/v3/n3/suppinfo/nn0300_238_S1.html

Raška, J., Štys, P., \& Exnerová, A. (2017). How variation in prey aposematic signals affects avoidance learning, generalization and memory of a salticid spider. Animal Behaviour, 130, 107-117. doi:https://doi. org/10.1016/j.anbehav.2017.06.012

Reader, S. M., Hager, Y., \& Laland, K. N. (2011). The evolution of primate general and cultural intelligence. Philosophical Transactions of the Royal Society London B, 366, 1017-1027. doi: https://doi.org/10.1098/rstb.2010.0342

Reader, S. M., \& Laland, K. N. (2002). Social intelligence, innovation, and enhanced brain size in primates. Proceedings of the National Academy of Sciences USA, 99, 4436-4441. doi:https://doi.org/10. 1073/pnas.062041299

Richards, R. J. (1987). Darwin and the emergence of evolutionary theories of mind and behavior: University of Chicago Press.

Riechert, S. E. (1982). Spider interaction strategies: Communication vs. coercion. In P. N. Witt, Rovner, J. S. (Ed.), Spider communication: Mechanisms and ecological significance. (pp. 281-314). Princeton, NJ: Princeton Univ. Press.

Roberts, J. A., Taylor, P. W., \& Uetz, G. W. (2006). Consequences of complex signaling: predator detection of multimodal cues. Behavioral Ecology, 18, 236-240. doi:https://doi.org/10.1093/ beheco/arl079

Rosati, A. G. (2017). Foraging cognition: Reviving the ecological intelligence hypothesis. Trends in Cognitive Sciences, 21, 691-702. doi: https://doi.org/10.1016/j.tics.2017.05.011

Safi, K., \& Dechmann, D. K. (2005). Adaptation of brain regions to habitat complexity: A comparative analysis in bats (Chiroptera). Proceedings of the Royal Society of London B, 272, 179-186. doi: https://doi.org/10.1098/rspb.2004.2924

Schiff, W., Caviness, J. A., \& Gibson, J. J. (1962). Persistent fear responses in rhesus monkeys to the optical stimulus of 'Looming'. Science, 136, 982-983. doi:https://doi.org/10.1126/science.136. 3520.982

Schultheiss, P., Schwarz, S., Cheng, K., \& Wehner, R. (2013). Foraging ecology of an Australian salt-pan desert ant (genus Melophorus). Australian Journal of Zoology, 60, 311-319. doi:https://doi.org/10. 1071/ZO12096

Schultheiss, P., Stannard, T., Pereira, S., Reynolds, A. M., Wehner, R., \& Cheng, K. (2016). Similarities and differences in path integration and search in two species of desert ants inhabiting a visually rich and a visually barren habitat. Behavioral Ecology \& Sociobiology, 70, 1319-1329. doi:https://doi.org/10.1007/s00265-016-2140-0

Schwartz, B. L., Meissner, C. A., Hoffman, M., Evans, S., \& Frazier, L. D. (2004). Event memory and misinformation effects in a gorilla (Gorilla gorilla gorilla). Animal Cognition, 7, 93-100. doi:https:// doi.org/10.1007/s10071-003-0194-7

Schwarz, S., \& Cheng, K. (2010). Visual associative learning in two desert ant species. Behavioral Ecology \& Sociobiology, 64, 20332041. doi:https://doi.org/10.1007/s00265-010-1016-y

Seyfarth, E. A., Hergenröder, R., Ebbes, H., \& Barth, F. G. (1982). Idiothetic orientation of a wandering spider: Compensation of detours and estimates of goal distance. Behavioral Ecology \& Sociobiology, 11, 139-148. doi:https://doi.org/10.1007/ BF00300103

Sherry, D. F., \& Vaccarino, A. L. (1989). Hippocampus and memory for food caches in black-capped chickadees. Behavioral Neuroscience, 103, 308-318. doi:https://doi.org/10.1037/0735-7044.103.2.308

Sherry, D. F., Vaccarino, A. L., Buckenham, K., \& Herz, R. S. (1989). The hippocampal complex of food-storing birds. Brain, Behavior and Evolution, 34, 308-317. doi:https://doi.org/10.1159/000116516

Shettleworth, S. J. (2010). Cognition, evolution and behavior (Second). New York: Oxford University Press.

Shultz, S., \& Dunbar, R. I. M. (2006). Both social and ecological factors predict ungulate brain size. Proceedings of the Royal Society of London B, 273, 207-215. doi:https://doi.org/10.1098/rspb.2005. 3283

Shultz, S., \& Dunbar, R. I. M. (2007). The evolution of the social brain: anthropoid primates contrast with other vertebrates. Proceedings of the Royal Society of London B, 274, 2429-2436. doi:https://doi.org/ 10.1098/rspb.2007.0693

Sih, A. (1992). Prey uncertainty and the balancing of antipredator and feeding needs. American Naturalist, 139, 1052-1069. doi:https:// doi.org/10.1086/285372

Skow, C. D., \& Jakob, E. M. (2005). Jumping spiders attend to context during learned avoidance of aposematic prey. Behavioral Ecology, 17, 34-40. doi:https://doi.org/10.1093/beheco/ari094

Smith, M. E., \& Belk, M. C. (2001). Risk assessment in western mosquitofish (Gambusia affinis): Do multiple cues have additive effects? Behavioral Ecology \& Sociobiology, 51, 101-107. doi: https://doi.org/10.1007/s002650100415

Sol, D. (2009). Revisiting the cognitive buffer hypothesis for the evolution of large brains. Biology Letters, 5, 130-133. doi:https://doi.org/ 10.1098/rsbl.2008.0621

Sol, D., Duncan, R. P., Blackburn, T. M., Cassey, P., \& Lefebvre, L. (2005). Big brains, enhanced cognition, and response of birds to novel environments. Proceedings of the National Academy of Sciences USA, 102, 5460-5465. doi:https://doi.org/10.1073/pnas. 0408145102

Stankowich, T., \& Blumstein, D. T. (2005). Fear in animals: A metaanalysis and review of risk assessment. Proceedings of the Royal Society of London B, 272, 2627-2634. doi:https://doi.org/10.1098/ rspb.2005.3251

Steinhoff, P.O.M., Sombke, A., Liedtke, J., Schneider, J.M., Harzsch, S., \& Uhl, G. (2017). The synganglion of the jumping spider Marpissa muscosa (Arachnida: Salticidae): Insights from histology, immunohistochemistry and microCT analysis. Arthropod Structure and Development, 46, 156-170. doi:https://doi.org/10.1016/j.asd.2016. 11.003

Steinhoff, P.O.M., Uhl, G., Harzsch, S., \& Sombke, A. (2020). Visual pathways in the brain of the jumping spider Marpissa muscosa. Journal of Comparative Neurology, 528, 1883-1902. doi:https:// doi.org/10.1002/cne.24861

Stephan, H., Nelson, J. E., \& Frahm, H. D. (1981). Brain size comparison in Chiroptera. Journal of Zoological Systematics and Evolutionary 
Research, 19, 195-222. doi:https://doi.org/10.1111/j.1439-0469. 1981.tb00239.x

Stephens, D. W., \& Krebs, J. R. (1986). Foraging theory. Princeton, NJ: Princeton University Press.

Striedter, G. F. (2005). Principles of brain evolution. Sunderland, MA.: Sinauer Associates Inc.

Tarsitano, M. S. (2006). Route selection by a jumping spider (Portia labiata) during the locomotory phase of a detour. Animal Behaviour, 72, 1437-1442. doi:https://doi.org/10.1016/j.anbehav. 2006.05.007

Tarsitano, M. S., \& Andrew, R. (1999). Scanning and route selection in the jumping spider Portia labiata. Animal Behaviour, 58, 255-265. doi:https://doi.org/10.1006/anbe.1999.1138

Tarsitano, M. S., \& Jackson, R. R. (1992). Influence of prey movement on the performance of simple detours by jumping spiders. Behaviour, 123, 106-120. doi:https://doi.org/10.1163/ $156853992 X 00147$

Tarsitano, M. S., \& Jackson, R. R. (1994). Jumping spiders make predatory detours requiring movement away from prey. Behaviour, 131, 65-73. doi:https://doi.org/10.2307/4535228

Tarsitano, M. S., \& Jackson, R. R. (1997). Araneophagic jumping spiders discriminate between detour routes that do and do not lead to prey. Animal Behaviour, 53, 257-266. doi:https://doi.org/10.1006/anbe. 1996.0372

Taylor, L. A., Amin, Z., Maier, E. B., Byrne, K. J., \& Morehouse, N. I. (2016). Flexible color learning in an invertebrate predator: Habronattus jumping spiders can learn to prefer or avoid red during foraging. Behavioral Ecology, 27, 520-529. doi:https://doi.org/10. 1093/beheco/arv182

Tork, P. (2018). Pathways of ocular entrainment in Marpissa marina (Araneae, Salticidae). New Zealand Journal of Zoology, 46, 321333. doi:https://doi.org/10.1080/03014223.2018.1549084

Uetz, G. W., \& Roberts, J. A. (2002). Multisensory cues and multimodal communication in spiders: Insights from video/audio playback studies. Brain, Behavior and Evolution, 59, 222-230. doi:https://doi.org/ 10.1159/000064909

van Praag, H., Kempermann, G., \& Gage, F. H. (2000). Neural consequences of environmental enrichment. Nature Reviews Neuroscience, 1, 191-198. doi:https://doi.org/10.1038/35044558

VanderSal, N.D., \& Hebets, E.A. (2007). Cross-modal effects on learning: a seismic stimulus improves color discrimination learning in a jumping spider. Journal of Experimental Biology, 210, 3689-3695. doi:https://doi.org/10.1242/jeb.009126
Ward, A. J. W., \& Mehner, T. (2010). Multimodal mixed messages: The use of multiple cues allows greater accuracy in social recognition and predator detection decisions in the mosquitofish, Gambusia holbrooki. Behavioral Ecology, 21, 1315-1320. doi:https://doi.org/ 10.1093/beheco/arq152

Wehner, R., \& Wehner, S. (1990). Insect navigation: Use of maps or Ariadne's thread? Ethology, Ecology \& Evolution, 2, 27-48. doi: https://doi.org/10.1080/08927014.1990.9525492

Wesołowska, W. 1999. A revision of the spider genus Menemerus in Africa (Araneae: Salticidae). Genus, 10, 251-353.

Wiggins, W.D., Bounds, S. \& Wilder, S.M. (2018). Laboratory-reared and field-collected predators respond differently to same experimental treatments. Behavioral Ecology \& Sociobiology, 72, article: 19. doi:https://doi.org/10.1007/s00265-017-2437-7.

Williams, B. M., Luo, Y., Ward, C., Redd, K., Gibson, R., Kuczaj, S. A., \& McCoy, J. G. (2001). Environmental enrichment: Effects on spatial memory and hippocampal CREB immunoreactivity. Physiology \& Behavior, 73, 649-658. doi:https://doi.org/10.1016/S00319384(01)00543-1

Williams, D. S., \& McIntyre, P. (1980). The principal eyes of a jumping spider have a telephoto component. Nature, 288, 578-580. doi: https://doi.org/10.1038/288578a0

World Spider Catalog (2019). Version 20.5 Natural History Museum Bern, online at http://wsc.nmbe.ch, accessed on 14/11/2019. doi: $10.24436 / 2$.

Zurek, D. B., Cronin, T. W., Taylor, L. A., Byrne, K., Sullivan, M. L. G., \& Morehouse, N. I. (2015). Spectral filtering enables trichromatic vision in colorful jumping spiders. Current Biology, 25, R403RR404. doi:https://doi.org/10.1016/j.cub.2015.03.033

Zurek, D.B., \& Nelson, X.J. (2012a). Hyperacute motion detection by the lateral eyes of jumping spiders. Vision Research, 66, 26-30. doi: https://doi.org/10.1016/j.visres.2012.06.011

Zurek, D.B., \& Nelson, X.J. (2012b). Saccadic tracking of targets mediated by the anterior-lateral eyes of jumping spiders. Journal of Comparative Physiology A, 198, 411-417. doi:https://doi.org/10. 1007/s00359-012-0719-0

Zurek, D. B., Taylor, A. J., Evans, C. S., \& Nelson, X. J. (2010). The role of the anterior lateral eyes in the vision-based behaviour of jumping spiders. Journal of Experimental Biology, 213, 2372-2378. doi: https://doi.org/10.1242/jeb.042382

Publisher's note Springer Nature remains neutral with regard to jurisdictional claims in published maps and institutional affiliations. 